\title{
İstanbul Boğazı'ndan Geçen Gemilerin Oluşturduğu Trafik Yükünün Çevresel Etkileri: Ro-Ro Gemileri Özelinde Bir İnceleme
}

\author{
Environmental Effects of Traffic Load of Ships Passing through the \\ Istanbul Strait: An Examination on the Ro-Ro Ships
}

Ersoy KUTLUK

\section{Öz}

Denizyolu taşımacıllğı dünya ticaretinde çok önemli bir işlev görmektedir. Maliyetlerin düşük olması ve nakliye sürecinde bürokratik engellerin olmaması bu taşımacılık türüne fonksiyonellik kazandırmaktadır. Ancak denizyolu taşımacılığı aynı zamanda deniz ve hava kirliliğine neden olmakta, çeşitli nedenlerle ekosistemlere zarar vermektedir. Günümüzde denizler sadece taşımacılık faaliyetleri nedeniyle değil karasal boşaltımlar ve denizlerde meydana gelen kazalar gibi nedenlerle de ciddi bir kirlilik tehdidi ile karşı karşıyadırlar. Küresel nitelik taşıyan bu sorunun çözümü için özellikle IMO öncülüğünde çalışmalar yapılmaktadır. Deniz kirliliği Türkiye’nin de gündeminde bulunmaktadır. Deniz kirliliği sorununun çözümü doğrultusunda ulusal düzeyde çalışmalar yapılmakta ve uluslararası katılımlar gerçekleştirilmektedir. Türkiye ve özellikle de Türk Boğazları bu yoğun deniz trafiği ve deniz kirliliğinden etkilenmektedir. İstanbul Boğazı ele alındığında ise onun denizyolu taşımacılığı açısından öneminin gittikçe arttığı ve buna bağlı olarak deniz kirliliği sorunuyla artan bir şekilde yüzleştiği görülmektedir. İstanbul Boğazı’nın uluslararası statüsü Lozan Boğazlar Sözleşmesi’nin revize edilmiş hali olan 1936 tarihli Montrö Boğazlar Sözleşmesi ile belirlenmiştir. Montrö Sözleşmesinin imzalandığ1 1936 yılından bu yana boğazlardaki yoğunluk önemli bir artış göstermiştir. İstanbul Boğazı’ndan yllda yaklaşı 50.000 geminin geçiş yaptığı bilinmektedir. Yoğun gemi trafiği, çevre üzerinde oluşan olumsuz etkiyi her geçen gün arttırmaktadır. Bu çalışma kapsamında İstanbul Boğazı’nda yaşanan çevresel sorunlar çeşitli boyutlarılya ele alınmıştır. Bu sorunların ortaya konulmasında deniz kirliliği ve hava kirliliğine ilişkin araştırmalar son derece önem taşımaktadır. Ancak gemilerden kaynaklanan negatif çevresel etkilerin tam anlaşılmasında deniz kirliliği ve hava kirliliğine ilişkin incelemeler yeterli olmamaktadır. Denizyolu taşımacılığı ve özellikle de gemilerin teknik özelliklerinden kaynaklanan bazı işlemler deniz çevresi üzerinde çözülmesi oldukça güç problemlere sebebiyet vermektedir. Çalışma kapsamında farklı gemi tiplerinin farklı negatif çevresel tesirler meydana getirdiği ortaya konulmuştur. Araştırmada gemi kaynaklı çevre kirliliğinin tespit edilmesi ve çevre yönetiminin planlanması sürecinde, farklı gemi tiplerine göre yapılacak analizlerin önem taşıdı̆̆ı öne sürülmektedir. $\mathrm{Bu}$ yaklaşımın ortaya konulacak politikalar ve geliştirilecek ulusal strateji için yeni bir bakış açısı kazandıracağı değerlendirilmektedir. Bu çerçevede Ro-Ro Gemilerinin hava kirliliği açısından diğer

* $\quad$ Yrd. Doç. Dr., Bandırma Onyedi Eylül Üniversitesi, İ̈BF, Siyaset Bilimi ve Kamu Yönetimi Bölümü, Siyaset ve Sosyal Bilimler Anabilim Dalı, ekutluk@bandirma.edu.tr 
birçok gemi tipine göre daha az olumsuzluğa neden olduğu belirtilmiştir. Ancak deniz kirliliği ve diğer negatif çevresel etkiler bağlamında dolaylı da olsa bu gemilerden kaynaklanan birçok olumsuzluğun ortaya çıkabileceği neticesine varılmış; pratik işleyişte ve yapılacak düzenlemelerde bu hususa dikkat edilmesi gerektiği sonucuna ulaşılmıştır.

Anahtar Kelimeler: Denizyolu Taşımacılığı, IMO, Deniz Kirliliği, Hava Kirliliği, Ekosistem, İstanbul Boğazı, Ro-Ro Gemileri.

\begin{abstract}
Maritime transport has an important role in world trade. The low costs and the lack of bureaucratic obstacles in the transportation process make maritime transportation a functional one. However, maritime transport also causes sea and air pollution and damages ecosystems for various reasons. Today, seas are faced with a serious threat of pollution not only due to transportation activities but also due to terrestrial discharges and accidents happening in the seas. In order to solve this global problem, studies are being carried out especially under the leadership of IMO. Marine pollution is on Turkey's agenda too. For the sake of the solution of the problem of marine pollution, studies are carried out at the national level and international participation is realized. Turkey and the Turkish Straits in particular are affected by this intense maritime traffic and marine pollution. When the Istanbul Strait is taken into consideration, it is seen that the importance of maritime transport has increased, and the maritime pollution problem has become increasingly confronted with it. The international status of the Bosphorus is determined by the revised version of the Lausanne Straits Convention of 1936, the Montreux Straits Convention. Since the signing of the Montreux Convention in 1936, the density in the straits has shown a significant increase. It is known that about 50,000 ships pass through the Bosphorus every year. Intensive ship traffic increases the negative effects on the environment every passing day. Within the scope of this study, the environmental problems in the Istanbul Strait were discussed in various dimensions. Research on marine pollution and air pollution is of the utmost importance in establishing these problems. However, in understanding the negative environmental impacts arising from the vessels, the studies on marine pollution and air pollution are not sufficient. Some operations resulting from maritime transport, and especially from the technical specifications of ships, present a very difficult problem to solve on the marine environment. Within the scope of the study, it has been revealed that different ship types bring different negative environmental influences. It is suggested that the analyzes to be done according to different ship types are important in determining the environmental pollution from the ship in the survey and planning of the environmental management. It is assessed that this approach will provide a new perspective on the policies to be put forward and the national strategy to be developed. Ro-Ro vessels in this framework are less vulnerable to air pollution than many other ship types. However, it has been concluded that there may be many negative consequences arising from these ships, even if indirectly in the context of marine pollution and other negative environmental impacts. In practical operation and in the regulations to be done, this situation has to be taken into consideration.
\end{abstract}

Keywords: Maritime Transportation, IMO, Sea Pollution, Air Pollution, Ecosystem, Istanbul Strait, Ro-Ro Ships.

\title{
Giriş
}

Çevre kirliliği bugün tüm insanlığı ve yeryüzünü tehdit eden küresel bir sorun halini almıştır. Makro boyutta yaşanan bu soruna uluslararası düzeyde çözüm üretme çabaları sürmekte, ülkeler uluslararası belgelere imza atarak sorumluluk almaya davet edilmektedir. Yeryüzünde yaşanan 
kirlilik problemi çok boyutludur ve dünya denizlerini de giderek artan oranda risk altında bırakmaktadır.

Denizler özellikle karasal deşarjlar / boşaltımlar sonucu kirletilmekle birlikte, uluslararası deniz taşımacılığı faaliyetlerinin yoğunlaşmasına bağlı olarak artan gemi kaynaklı kirlilik de önemli bir sorun teşkil etmeye başlamıştır. Ayrıca denizlerde insan hatalarına bağlı olarak meydana gelen kazalar da kirlilik nedenlerindendir.

Deniz taşımacılığı kaynaklı çevre kirliliği, 'deniz kirliliği’ ve ‘hava kirliliği’ olarak iki kısımda ele alınabilir. Ancak gemi kaynaklı negatif çevresel etkilerin sadece bunlarla sınırlı olmadığı da artık bilinmektedir. Uluslararası sularda seyreden gemiler farklı canlı türlerinin doğal olmayan şekilde yer değiştirmesine neden olabilmekte, temas ettikleri ekosistemleri çeşitli nedenlerle olumsuz etkileyebilmekte ve bu şekilde doğaya ve insana son derece zararlı olabilmektedirler.

Bir deniz ülkesi olan Türkiye’nin yaşanan bu sorunlardan etkilenmemesi mümkün gözükmemektedir. Yapılan araştırmalar Karadeniz, Ege ve Akdeniz ile birlikte Marmara ve Boğazların da büyük bir kirlilik tehdidi altında bulunduğunu ortaya koymaktadır (Çevre ve Şehircilik Bakanlığı, Çevresel Etki Değerlendirmesi, İzin ve Denetim Genel Müdürlüğü [CSB ÇİDGM], 2016, s. 83-91, CSB ÇİDGM, 2017, s. 66, Marmara Denizi’nin Değişen Oşinografik Şartlarının izlenmesi Projesi [MAREM], 2014, s. 399-402). Bu çalışmada odaklanılan İstanbul Boğazı, işlek bir uluslararası suyolu olması itibariyle denizyolu taşımacılığının küresel boyutta ortaya çıkardı̆̆ı sorunlarla fazlasıyla yüzleşmektedir.

Bu makale kapsamında gemi kaynaklı kirlilik sorunu ve diğer negatif çevresel etkiler İstanbul Boğazı'ndaki Ro-Ro gemi trafiği özelinde mevcut veriler ışı̆̆ında ele alınmaya çalışılmıştır. Konu üzerinde yapılan ve özellikle çevresel etkiyi ortaya koyan araştırmalar makalenin oluşumuna ışık tutmuştur. Çevre ve Şehircilik Bakanlığı ile Ulaştırma, Denizcilik ve Haberleşme Bakanlığ bünyesinde ve teşvikiyle yapılan çalışmalar; İstanbul Büyükşsehir Belediyesi’nin çalışmaları; Deniz Ticaret Odası'nın raporları; Marmara Denizi’nin Değişen Oşinografik Şartlarının İzlenmesi Projesi (MAREM) gibi süreklilik arz eden bilimsel projeler; düzenlenen bazı sempozyumlar ve kongrelerdeki bildiriler (I.Ulusal Denizlerde İzleme ve Değerlendirme Sempozyumu, 2016; Gemi İnşaatı ve Deniz Teknolojisi Teknik Kongresi, 1999; Marmara Belediyeler Birliği tarafından düzenlenen 'Derdimiz, Denizimiz, Değerimiz: Marmara' adlı sempozyum, 2013; Türkiyede Katı Atık Yönetimi Sempozyumu [TÜRKAY], 2009; Ulusal Lojistik ve Tedarik Zinciri Kongresi, 2016) ve ilgili bazı akademisyenlerin çalışmaları (Tuna ve Elbir, 2013; Özdemir ve Deniz, 2013; Küçük ve Topçu, 2012; Köseoğlu, Töz ve Şakar, 2016; Kılıç, 2009; İncecik ve İm, 2013; Cirik ve Akçalı, 2002; Ceyhan ve Esmeray, 2012; Başar, Erol ve Yılmaz, 2015; Ayat ve Yüksel, 2012) bu çerçevede anılabilir.

Makale, gemi kaynaklı çevre kirliliğinin değerlendirilmesi ve çevre yönetiminin planlanması sürecinde farklı gemi tiplerine göre yapılacak analizlerin oluşturulacak politikalar ve geliştirilecek ulusal strateji için yeni bir bakış açısına imkan sağlayacağı ana fikri üzerine inşa edilmiştir. Sorunun analizinin ve mikro düzeyde tespit edilmesinin, problemi oluşturan faktörlere ve 
özelliklerine farklı yaklaşımlar geliştirilmesine ve bunlarla ilgili özgün çözümler üretilmesine katkı sağlayacağı düşünülmüştür.

\section{Uluslararası Denizyolu Taşımacılığı ve Oluşturduğu Çevresel Sorunlar}

Denizyolu taşımacılığı gerek maliyet avantajı gerek işlem kolaylığı yönünden (gümrük işlemleri, sınır geçişi vb.) dünya ticaretinde daha çok tercih edilmektedir. 2015 yılında dünya deniz ticaret hacminin toplam dünya ticaret hacminin yüzde 80'inden fazlasını oluşturduğu tahmin edilmektedir (United Nations Conference on Trade and Development [UNCTAD], 2016, s. 6). Dünya ticaret hacmi denizyolu taşımacılığını etkileyen ana dinamik olarak ortaya çıkmaktadır. Yaklaşık olarak 60 trilyon dolar civarında olan Dünya Gayri Safi Milli Hasılası'nın 6 trilyon doları (\%10’u) lojistik sektöründen ${ }^{1}$, lojistik pazarın 3,6 trilyon dolarlık bölümü toplam taşımacılık hizmetlerinden, toplam taşımacılık payının yaklaşık 600 milyar dolarlık kısmının ise deniz taşımacılığı neticesinde elde edilen navlun gelirlerinden oluştuğu tahmin edilmektedir (Ulaştırma Bakanlığı [UB], 2011, s. 92).

Denizyolu taşımacılığının söz konusu artışına bağlı olarak değerlendirilebilecek olan deniz kirliliği, hava kirliliği ve diğer çevresel sorunlar günümüzde küresel boyuta ulaşmıştır. Küresel ölçekli temel çevre sorunları arasında yer alan 'sınıraşan su ve hava kirliliği' insanlığın önünde çözülmesi gereken önemli problemler olarak durmaktadır. "Çevre sorunları sınırları aşan nitelikleri itibariyle çok yönlü bir işbirliği ve eşgüdümü gerekli kılmaktadır” (Korkusuz, 2012, s. 662).

Uluslararası düzeyde denizcilik sektörünün üst kuruluşu olan IMO’nun (Uluslararası Denizcilik Örgütü) verilerine göre denizlerde meydana gelen kirliliğin nedeni olan atıkların \%8'i doğal kaynaklardan, \%0.5’i açık deniz üretiminden, \%11'i deniz taşımacılığından, \%30’u atmosferden, \%40’ı taşkın ve kara kökenli deşarjlardan, \%10’u kanunsuz boşaltma (gemilerden ve uçaklardan, karada ve denizde üretilen atıklar) dünya denizlerine girmektedir (Küçük ve Topçu, 2012, s. 77-78). Denizlerde oluşan kirlilik sorununa yönelik çalışmalarını sürdüren IMO denizcilik faaliyetlerinin güvenli ve verimli bir şekilde, temiz denizlerde yapılmasını kendisine misyon olarak belirlemiştir. IMO, 50'den fazla antlaşma (uluslararası sözleşme ve protokol) ile yüzlerce kod, yönerge ve tavsiye kararı hayata geçirmiştir (The International Maritime Organization [IMO], 2017a). IMO'nun ${ }^{2}$ temel kuruluş amacı deniz güvenliğinin arttırılması yönünde uluslararası mekanizmaları harekete geçirmektir. Faaliyet alanları ise uluslararası denizlerde seyir güvenliğinin sağlanması amacıyla teknik önlemleri almak ve gerekli uluslararası normların düzenlenmesine öncülük etmek; deniz işletmeciliğinde verimin yakalanması için en etkili kuralların kabulünü sağlamak; gemi kaynaklı kirliliğin önlenmesine yönelik olarak ülkeler arası işbirliğini temin etmektir (Ayan ve Baykal, 2010).

1 Lojistik terimi, bir ürünün üreticiden tüketiciye varışına kadar olan taşımacılık (karayolu, denizyolu, havayolu, demiryolu, boru hattı taşımacılığı ve kombine taşımacılık), depolama, gümrükleme, ambalajlama gibi tüm faaliyet sürecini ifade etmektedir (Müstakil Sanayici ve İşadamları Derneği [Müsiad], 2013, s. 15-21).

2 IMO’nun organizasyon yapısı Genel Kurul; Konsey (Genel Kurul tarafından seçilen icra organıdır); Deniz Güvenliği Komitesi (MSC) ve Deniz Çevresini Koruma Komitesi (MEPC) ile bunların alt komiteleri; Hukuk Komitesi; Teknik İşbirliği Komitesi; Kolaylaştırma Komitesi ve Sekreterya’dan oluşmaktadır (IMO, 2017b). 
Gemi kaynaklı kirlilik her ne kadar denizlerde meydana gelen kazalarda daha çok gündeme gelse de "gemi kaynaklı yasadışı deşarj (boşaltma) ve diğer kasti hareketler deniz çevresinin ne denli büyük bir riskle karşı karşıya olduğunu gözler önüne sermektedir." Küresel nitelik taşıan bu sorunun uluslararası platformda aşılması için IMO öncülügünde imzalanan MARPOL 73/78 adlı sözleşmenin (Gemilerden Kaynaklanan Kirliliğin Önlenmesi için Uluslararası Sözleşme) gereği olarak taraf devletler "limanlarına gelen gemilerde üretilen her türlü atığı etkin bir şekilde elleçlemek ${ }^{3}$, depolamak ve nihai bertarafa göndermek hususunda önemli sorumluluklara sahiptir” (Köseoğlu, Töz ve Şakar, 2016, s. 173).

Denizlerde oluşan gemi kaynaklı kirliliğin en önemli nedenleri: Gemilerde oluşan sintine, kirli balast veya ambar / tank yıkama sularının denize deşarj edilmesi; çöp ve benzeri evsel atıkların denize atılması; güvertelerin yıkanması neticesinde oluşan yağ ve atıklar ile bu esnada kullanılan deterjanlı suyun denize verilmesi; gemi bordasında (dış yüzeyin ilgili kısmında) denizi kirletecek şekilde raspa (yüzey temizlik işlemi) ve boya işlerinin yapılması; taşınan yüklerden kaynaklanan atıkların denize dökülmesi; güvertedeki kirletici atıkların yağmur suyu veya balast taşıntı suları ile denize verilmesi; yakıt aktarımı sırasında yapılan hata nedeniyle (taşma, sızma vb.) yakıtın denize taşması; "gemi makinesinin soğutma suyuna yă̆ karışarak soğutma suyuyla beraber denize akmast; şaft sızdırmazlık yağının denize kaçmasl; güvertelerdeki hidrolik devresinin patlaması sonucu akan yağın açık olan frengilerden denize akması;" gemideki yaşam yerlerinde oluşan kirli suların arıtılmaksızın denize bırakılmasıdır (Özdemir, 2012, s. 375).

Denizyolu taşımacılığından kaynaklanan kirliliğin sadece denizleri etkilemediği, taşımacılık faaliyetleri esnasında hava kirliliğinin de oluştuğu belirtilmelidir. Deniz taşımacılığından kaynaklanan emisyonların ${ }^{4}$ yaklaşık \%70’inin kıyı şeritlerinde ve liman bölgelerinde oluştuğu bilinmektedir (Aström ve Ab'den aktaran Tuna ve Elbir, 2013, s. 1). Oluşan bu kirleticilerin başında azot oksitler $\left(\mathrm{NO}_{\mathrm{x}}\right)$ ve kükürt dioksit $\left(\mathrm{SO}_{2}\right)$ gelmekte ve bu kirleticilerin küresel ölçekte azaltılmaları amacıyla çalışmalar yapılmaktadır (Tuna ve Elbir, 2013, s. 1). İnsan sağlığını en olumsuz şekilde etkileyen azot oksit türü olan $\mathrm{NO}_{2}$ kentsel bölgelerde tehlike arz eden hava kirleticilerinden biridir. İnsanların çok yüksek $\mathrm{NO}_{2}$ derişimlerine (konsantrasyon) kısa süre de olsa maruz kalmaları ciddi akciğer tahribatlarına yol açabilmektedir. "Kronik akciğer rahatsızliğ olan kişilerin ise bu derişimlere maruz kalmaları, akciğerde kısa vadede fonksiyon bozukluklarına yol açabilir. $\mathrm{NO}_{2}$ derişimlere uzun süre maruz kalınması durumunda ise buna bağh olarak solunum yolu rahatsızliklarının ciddi oranda arttığı gözlenmektedir" (İstanbul Çevre ve Şehircilik İl Müdürlüğü [İST CSB], 2016, s. 7).

3 Gümrük Kanununun (Kanun Numarası: 4458, Kabul Tarihi: 27/10/1999, Yayımlandığ1 Resmi Gazete: Tarih: 4/11/1999 Sayı: 23866, Yayımlandığı Düstur: Tertip: 5 Cilt: 394458 sayılı) 3. Maddesinde yer alan tanıma göre elleçleme: "gümrük gözetimi altındaki eşyanın asli niteliklerini değiştirmeden istiflenmesi, yerinin değiştirilmesi, büyük kaplardan küçük kaplara aktarılması, kapların yenilenmesi veya tamiri, havalandırılması, kalburlanması (ayıklamadan geçirilmesi), karıştırılması ve benzeri işlemleri" ifade etmektedir.

4 Çevre ve Şehircilik Bakanlığı tarafından çıkarılan Sanayi Kaynaklı Hava Kirliliğinin Kontrolü Yönetmeliğinde Değişiklik Yapılmasına Dair Yönetmeliğin (Çevre ve Şehircilik Bakanlığı, Yayımlandığı Resmi Gazete: Tarih: 20/12/2014 Sayı: 29211) 4. Maddesinde yer aldığı şekilde emisyon terimi "yakıt ve benzerlerinin yakılmasıyla; sentez, ayrışma, buharlaşma ve benzeri işlemlerle; maddelerin yiğılması, ayrılması, taşınması ve diğer mekanik işlemler sonucu bir tesisten atmosfere yayılan hava kirleticilerini" ifade eder. 
Avrupa'yı çevreleyen Baltık Denizi, Kuzey Denizi, Kuzey Doğu Atlantik, Akdeniz ve Karadeniz'deki uluslararası ticaret ile bağlantılı deniz yolu trafiğinden 2000 yılında atmosfere toplam 2.3 milyon ton $\mathrm{SO}_{2}, 3.3$ milyon ton $\mathrm{NO}_{x}, 250.000$ ton $\mathrm{PM}$ (partikül madde) salındiğ 1 tahmin edilmektedir. Deniz ticaretindeki artışın öngörüldüğü şekilde artmaya devam etmesi durumunda ise 2020 yılında deniz yolu ulaşımından kaynaklanan $\mathrm{SO}_{2}$ ve $\mathrm{NO}_{\mathrm{x}}$ emisyonlarının \%45-50 oranında artış göstereceği hesaplanmaktadır (AirClim, Seas At Risk, Bellona Foundation, North Sea Foundation, Transport \& Environment, European Environmental Bureau, 2011, s. 2). Denizyolu trafiği kaynaklı emisyonlardan partikül madde insan sağlığına zararlı en önemli kirleticilerden biridir. PM solunum sisteminin en hassas bölgelerine nüfuz edebilmektedir. Partiküler madde, $\mathrm{PM}_{10}$ ve $\mathrm{PM}_{2.5}$ olarak iki şekilde ele alınabilmektedir. " $P M_{10}$ kaynakları duman ve toz şeklinde sanayi tesislerinden, zirai emisyonlardan ve yollardan oluşmaktadır. $P M_{2.5}$ ise uçucu organik bileşikler, ağır metaller, trafik ve orman yangınları ile bağlantılıdır." $\mathrm{PM}_{2.5}$ insan sağlığına etkileri bakımından $\mathrm{PM}_{10}$ 'a nazaran daha tehlikelidir. Partiküller küçüldükçe akciğerlere daha rahat ulaşabilmektedir. Ayrıca küçük çaplı partiküller kapalı ortamlara kadar girebilmektedir. Bu tip partiküller kalp ve solunum yollarında problemlere sebebiyet vererek ölüm oranlarında artışlara neden olabilmektedir. Avrupa Çevre Ajansı tarafından hazırlanan hava kalitesi raporu, 2012 yılında Avrupa'da $\mathrm{PM}_{2.5}$ konsantrasyonlarına uzun süreli maruz kalma nedeniyle yaklaşık 432.000 erken ölümün gerçekleştiğini göstermektedir (European Environment Agency [EEA], 2015, s. 9).

Deniz kirliliğini önlemek amacıyla oluşturulan MARPOL 73/78 çerçevesinde yapılan sınıflandırma ile çerçevesi çizilen EK VI (Gemilerden Kaynaklanan Hava Kirliliği) adlı belge ile "ozon tabakasina zarar veren gazların salınımin önlenmesi ile gemilerin baca (egzos) gazlarından çıkan azot oksit (NOx) ve kükürt oksit (SOx) içeren emisyonların sınırlandırılmasına ilişkin yeni düzenlemeler getir(il)mektedir" (Köseoğlu, Töz ve Şakar, 2016, s. 159-160). Ayrıca IMO’nun komitelerinden MEPC (Deniz Çevresinin Korunması Komitesi) tarafından gündeme getirilen "Enerji Verimliliği Dizayn İndeksi (EEDI) ve piyasa esasl kontrol tedbirleri gibi düzenlemeler" aracılığıla gemi kaynaklı emisyon sorunuyla mücadele edilmeye çalışılmaktadır (UB, 2011, s. 103, Deniz Ticaret Odası [DTO], 2017).

1982 tarihli Birleşmiş Milletler Deniz Hukuku Sözleşmesi'nde, deniz çevresinin kirlenmesi, "canlı kaynaklara ve deniz yaşamına zarar verme, insan sağh l̆ğ için tehlike oluşturma, balıkçılık ve denizlerin diğer yasal amaçlarla kullanımı da dâhil olmak üzere, denizcilik faaliyetlerini engelleme, deniz suyunun niteliğini değiştirme ve güzellikleri bozma gibi zararl etkileri olan veya olabilecek maddelerin veya enerjinin" doğrudan ya da dolaylı olarak, deniz çevresine bırakılması olarak ifade edilmektedir. Sözleşmede deniz kirliliğine yol açan nedenler; "Kara kaynakl kirlenme; Ulusal yetkiye tabi deniz yatağı faaliyetlerinden ileri gelen kirlenme; Damping (boşaltma)/suya batırma kaynakl kirlenme; Gemilerden kaynaklanan kirlenme (Kasdi/işletimsel boşaltmalar - Kasdi olmayan/kaza sonucu kirletme; Atmosferden kaynaklanan veya atmosfer yoluyla oluşan kirlenme" başlıkları altında toplanabilir (Kubilay, 2014, s. 41). IMO tarafından yayınlanan 'Denizlerin Gemilerden Kirlenmesini Önleme Uluslararası Sözleşmesi (MARPOL)' konvansiyonunda ise boşaltımdan kaynaklanan kirlilik (kanalizasyon, yağlı atık, çöp, emisyon, zehirli atık, 
mikroorganizmalar, anti-fouling boyalar, kimyasallar) ve kazalardan kaynaklanan kirlilik olmak üzere ikili bir ayrım söz konusudur (Köseoğlu, Töz ve Şakar, 2016, s. 155).

Uluslararası nitelik taşıyan bazı belgelerde gemilerden kaynaklanan olumsuz çevresel etkilere deniz ve hava kirliliğini aşan bir kapsamda yaklaşıldığı ve çözüm arandığg görülmektedir. 3 Şubat 2004 tarihinde IMO tarafından imzaya açllan Gemi Balast Suyu ve Sedimanlarının Kontrolü ve Yönetimi Hakkında Uluslararası Sözleşme bu çerçevede hayata geçirilmektedir (IMO, 2017c). Sözleşme, zararlı organizmalar ve patojenlerin balast su tankları içerisinde taşınması neticesinde ekoloji, ekonomi ve sağlık açısından oluşan sorunların çözümü için önem taşımaktadır. Bu noktada ayrıca gemi yüzeylerinde organizmaların birikmesini önlemek için kirlenme önleyici sistemlerin (anti-fouling systems) kullanılmasına da IMO tarafından önem verilmektedir (IMO, 2011, s. 8).

Gemi balast sularının dünya çapındaki yer değişimi deniz çevresi üzerinde problemlere neden olmaktadır (balast suyu esasen geminin boşken dengesini sağlama işlevi görmekte, yük alınma sürecinde denize deşarj edilmektedir). Yapılan tahminlere göre her yıl yaklaşık 3-5 milyar ton balast suyunun dünya çapında transferi gerçekleşmektedir. Bu yolla taşınan istilacı deniz canlıları deniz çevresi için ciddi bir problem halini almıştır. Gerçekleşen bu transfer ile dünya çapında her gün 7.000 ile 10.000 kadar farklı deniz mikrobu, bitki ve hayvan türünün taşındığı tahmin edilmektedir (Globallast.imo.org, 2017).

Ekosistemleri bozan canlı türlerinin yeni ortamlara giriși sadece balast suları yoluyla olmamaktadır. Bu canlı türlerinin kanal açma çalışmaları neticesinde ait olmadıkları ortamlara geçişi (Örneğin Süveyş Kanalı) de mümkün olmaktadır. Ayrıca bu canlıların gemi karinalarına tutunmaları sonucu taşınmaları da dikkat çekmektedir. Cirik ve Akçalı’nın da belirttiği gibi "gemi karinaları üzerinde gelişen yapışıcı ve tutunucu organizmalar (fouling ve boring türler) denizel canlıların bir yerden başka bir yere taşınımında önemli yer tutmaktadırlar" (2002, s. 509). Farklı deniz ortamlarında yaşayabilen bu canlıların oluşturduğu çevresel zarar, gerek uzun denilebilecek bir zaman diliminde ortaya çıkmasından gerekse de somut olarak kolayca görülememesinden dolayı, dikkatleri yeterince çekmemekte ancak etkisi büyük olmaktadır.

Gemi Balast Suyu ve Sedimanlarının Kontrolü ve Yönetimi Hakkında Uluslararası Sözleşme’ye 2014 yılında taraf olan Türkiye’nin deniz çevresinin kirliliği konusundaki yükümlülükleri diğer bazı uluslararası sözleşmelerden ${ }^{5}$, bölgesel sözleşmelerden (Barcelona Sözleşmesi 1976; Bükreş Sözleşmesi 1992), ikili anlaşmalardan ve iç hukuktan kaynaklanmaktadır (Kubilay, 2014, s. 42, Küçük ve Topçu, 2012, s. 78-79). Gemi kaynaklı kirlilik sorunu ulusal düzeyde gerçekleştirilen çalışmalar ve Türkiye’nin uluslararası platformlarda gerçekleştirdiği katılımlarla gündemde bulunmaktadır.

5 IMO Sözleşmeleri: MARPOL 73/78 Sözleşmesi; Petrol Kirliliğine Karşı Hazırlıklı Olma, Müdahale ve İşbirliğine Dair Uluslararası Sözleşme (OPRC 1990); Petrol Kirliliği Zararlarından Doğan Sivil Sorumluluklar Hakkında Uluslararası Sözleşme (CLC 1969); Petrol Kirliliği Zararları İçin Uluslararası Tazminat Fonu Kurulmasına İlișkin Uluslararası Sözleşme (FUND 1971) (Ayrıca bakınız: Ulaştırma Denizcilik ve Haberleşme Bakanlı̆̆ı, IMO Mevzuatı Bilgi Sistemi [IMO.UDHB], 2017). 


\section{İstanbul Boğazı'nda Uluslararası Denizyolu Taşımacılığı ve Gemi Kaynaklı Çevre Kirliliği}

\section{İstanbul Boğazı'nın Deniz Taşımacılığı Açısından Önemi}

Boğazlar denizleri ve okyanusları kısa yoldan birbirine bağlayan doğal suyollarıdır. Dünya üzerinde Akdeniz ile Atlas Okyanusunu Cebelitarık; Basra Körfezi ile Hint Okyanusunu Hürmüz; Güneydoğu Asya’da Malakka Yarımadası ile Sumatra Adasını Malakka; Amerika’nın güneyinde Atlas Okyanusu ile Pasifik Okyanusunu Magellan; Kuzey Denizi ile Baltık Denizini Sunt ve Büyük Belt; Kızıl Deniz ile Aden Körfezini Babülmendep; Bering Denizi ile Kuzey Buz Denizini Bering Boğazları birbirlerine bağlamaktadırlar. Ayrıca denizleri birbirine bağlamak için kanal açma çalışmaları da 19.Yüzyıl'dan itibaren geçmişe göre daha yoğun bir şekilde hayata geçirilmiştir. Bu çalışmalar neticesinde Kızıl Deniz ve Akdeniz Süveyş; Atlas ve Pasifik Okyanusları Panama; Baltık Denizi ve Kuzey Denizi Kiel; İyon Denizi ile Ege Denizi Korint Kanalları ile birbirlerine bağlanmışlardır (Taşlıgil, 2004, s. 2).

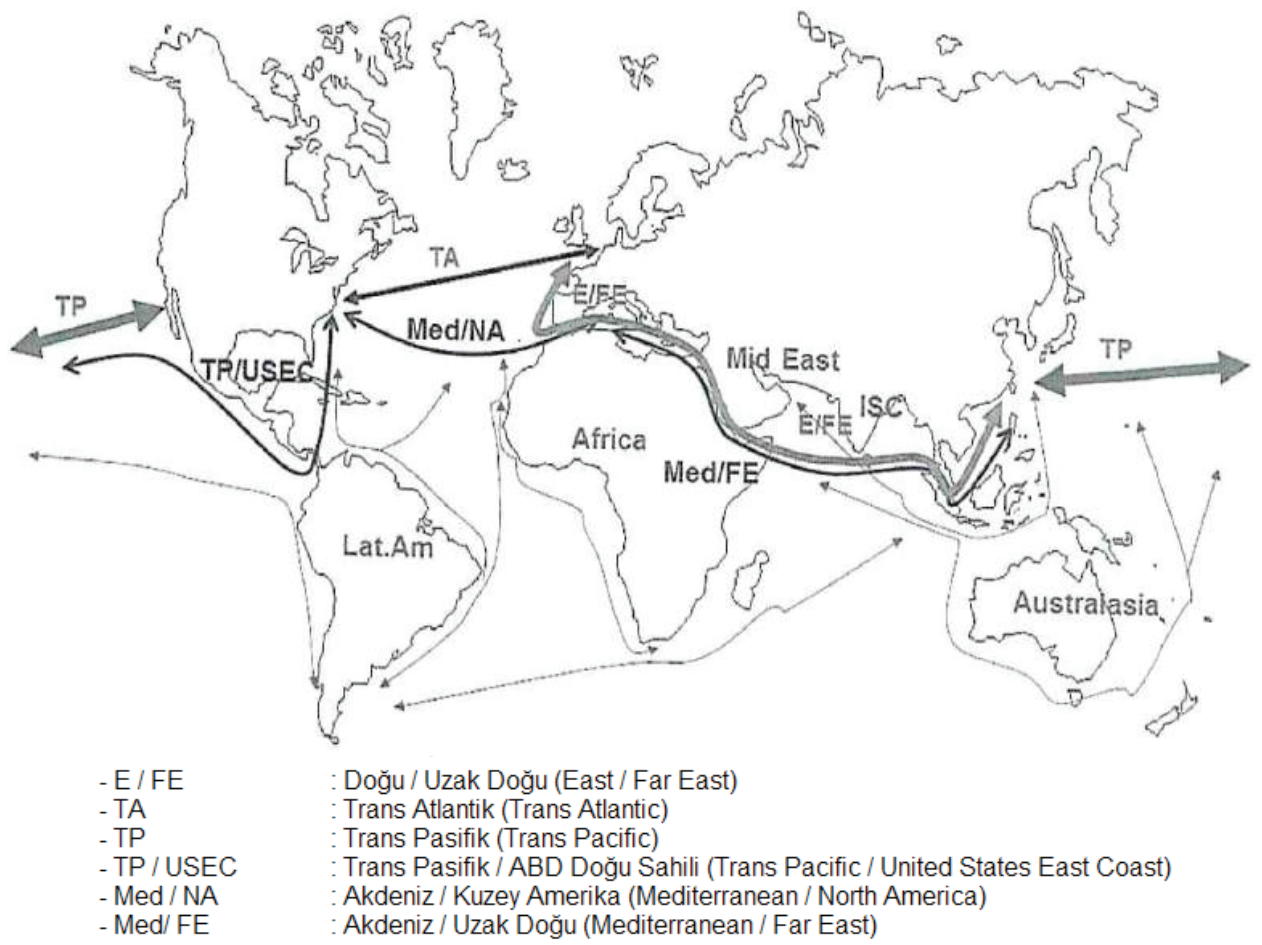

Şekil 1: Ana Deniz Ticareti Rotaları (DTO, 2016, s. 15).

Dünya üzerindeki ana deniz ticareti yolları / rotaları yukarıda Şekil 1'de sunulmaktadır. Boğazların ve insan yapımı kanalların uluslararası deniz ticareti için oldukça önemli olduğu gözükmektedir. İstanbul Boğazı da denizyolu taşımacılığındaki gittikçe artan önemiyle dikkatleri çekmektedir. İstanbul Boğazı, Rusya Federasyonu, Romanya, Bulgaristan, Ukrayna, Gürcistan gibi Karadeniz’e 
kıyısı olan ülkelerin; Tuna güzergâhı üzerinden bağlantı kurabilecek ülkelerin'; Hopa ve Trabzon Limanları aracılığıyla İran’ın denizlere açılan kapısıdır (Taşlıgil, 2004, s. 3).

İstanbul Boğazı’nda uygulamadaki transit geçiş şartları 1936 tarihli Montreux (Montrö) Antlaşması ile belirlenmiştir. Antlaşma Türkiye’de 31 Temmuz 1936 tarihinde 3056 sayılı kanunla yürürlüğe girmiştir. Montreux ile bayrağı ve yüküne bakılmaksızın ticaret gemilerinin günün her saatinde İstanbul Boğazı’ndan transit olarak geçmelerine serbestlik tanınmıştır. Geçiş yapan gemilerin ücretli kılavuz almaları ya da romorkör istemeleri tercihe bağlıdır (Taşlıgil, 2004, s. 3-4). Türkiye Cumhuriyeti Dışişleri Bakanlığı’nın paylaştığı verilere göre "1936 yılında İstanbul Boğazından günde yalnız 17 gemi geçmekte iken, 2009 yılında İstanbul Boğazından geçen (toplam) gemi sayısı 51422'dir. Bu rakam günde ortalama 140 gemiye tekabül etmektedir.” Görüldüğü üzere Montrö Sözleşmesinin imzalandığı 1936 yılından bu yana boğazdan geçen gemi sayısı yaklaşık 8 kat artmıştır. Ortaya konan şu istatistiksel veri de dikkat çekmektedir ki, "Türk Boğazlarındaki deniz trafiği, Süveyş Kanalindaki deniz trafiğinden üç kat daha fazladır” (Türkiye Cumhuriyeti Dışişleri Bakanlığı [MFA], 2017a).

Boğazlardan geçen gemilerin büyük bir kısmı "zehirli, tehlikeli ve patlayıcı madde (ham petrol, amonyak, sıvılaştırılmış gaz, radyoaktif maddeler, tehlikeli atıklar gibi) taşımaktadır." Özellikle Sovyet Sosyalist Cumhuriyetler Birliğìnin (SSCB) yıkılışını takip eden 1990'lı yıllardan itibaren, alıcılara sevk amacıyla Karadeniz'deki limanlara aktarılan petrolün artışına paralel olarak, Boğazlardan geçen tehlikeli madde ve petrol taşıyan gemilerin sayısında ciddi oranda artış yaşanmıştır. 19962009 döneminde boğazlarda tanker trafiği \%218 artışla 2009'da 9299 tankere, yine Boğazlardan geçirilen tehlikeli madde miktarı ise yaklaşık \%240 oranında artarak 2009'da 144.6 milyon tona ulaşmıştır. Bu durum şu şekilde ifade edilmektedir ki, "bugün Türk Boğazları yoluyla, en çok petrolün taşındiğı boru hattından daha fazla tehlikeli madde taşınmaktadır." Taşınan tehlikeli madde miktarının yıldan yıla artışı Boğazları daha da riskli hale getirmektedir. Bu riskin azaltılması ve Boğazlarda seyir, can, mal ve çevre güvenliğinin artırılması için, birbiriyle bağlantılı bir dizi önlem uygulamaya konmuştur. Türk Boğazları Tüzüğü ve "Denizde Çatışmayı Önleme Uluslararası Sözleşmesi (COLREG) uyarınca, gemilerin geçişlerinde uymakla yükümlü olacakları trafik ayırım şemaları" bu önlemlerdendir. "(Ayrıca) radar destekli Türk Boğazları Gemi Trafik Hizmetleri Sistemi (TBGTHS-VTS), 30 Aralı 2003 tarihinde operasyonel olarak devreye girmiştir” (MFA, 2017a). Tüm bu önlemlere rağmen Boğazlarda meydana gelebilecek bir kaza sonucunda "Marmara Denizindeki kararlı tabakalaşma nedeniyle petrol ve türevleri deniz yüzeyinde kalacaklarından petrol ve atıklarının denize dökülmesinin olumsuz etkileri açık denizlerle karşılaştırılamayacak boyutta yüksek olacaktır." Bu tip bir kaza en başta Boğazlar bölgesinde yaşayan insanların can ve mal güvenliğinin tehlikeye atacak, ayrıca ticaret için hayati öneme sahip olan ve Karadeniz’in tek çıkış kapısı olan Boğazların uzun süre geçişe kapalı kalmasına neden olabilecektir. Esasen boğazlar teknik anlamda güvenli

6 Avrupa Birliği’nin tespit ettiği ulaştırma koridorları arasında yer alan Tuna (Danube) Nehri Almanya, Avusturya, Slovakya, Macaristan, Hırvatistan, Sırbistan, Romanya, Bulgaristan, Moldova ve Ukrayna’yı yaklaşık 3.000 km uzunluğu ile birbirine bağlamaktadır. Tuna "doğrudan ya da dolayl olarak 40 Avrupa ülkesine ait milyonlarca ton yükü Batı Avrupa'dan Karadeniz'e kadar ulaştıran geniş bir otoban kimliğine sahip(tir)” (Uluslararası Taşımacılık ve Lojistik Hizmet Üretenleri Derneği [Utikad], 2017). 
olarak kaldırabileceği gemi trafiği kapasitesine ulaşmıştır ki, bu kapasitenin daha fazla zorlanması Boğazların emniyetine açık bir tehdit oluşturacaktır. Bu riski azaltıcı bir seçenek olarak "gerek mevcut alternatif boru hatlarının daha etkin kullanılması, gerekse alternatif projelerin hayata geçirilmesi ile Boğazlar üzerinden taşınan petrol miktarının çok büyük kısmının dünya piyasalarına ulaştırılması mümkündür” (Tozar ve Güzel, 2011, s. 12).

Boğazlarda oluşan trafik yükü ile bağlantılı olan ülkelerden Rusya Federasyonu’nun, enerji kaynağ 1 ithalatında alternatif boru hattı seçeneklerine rağmen bu deniz yolunu kullanma tutumunu sürdürdüğü görülmektedir. Rusya Federasyonu, "Türkiye’nin güvenlik gerekçesiyle getirdiği kısıtlamalara karşı doğalgaz fiyatı ve oranı üzerindeki karar vericiliğini silah olarak kullanmaktadır" (Uğurlu, 2009, s. 374). Rusya Federasyonu’nun Akdeniz’e açılan önemli limanı Novorossisk ${ }^{7}$ (Novarasîsk) yıl boyunca deniz taşımacılığına açık olup yıllık 113 milyon tonla kargo işlem hacmi bakımından ülkenin en büyük limanı hüviyeti taşımaktadır. "Bu miktarın büyük kısmını petrol terminalinden yüklenen sıvı ham petrol oluşturmaktadır. Novorossisk Petrol Terminali, Rusya Federasyonu'nun petrol ihracatının \%60'inı gerçekleştirmektedir. Diğer terminaller ise konteynır, tahıl, kereste, genel kargo, inşaat malzemeleri, bitkisel yağlar, kömür ve metal taşımacılı̆̆ına hizmet vermektedir. Rusya'nın tahıl ihracatının \%24'̈̈ Novorossisk Limanindan yapılmaktadır" (MFA, 2017b). Rusya’nın petrol hatlarının çoğu Novorossisk Limanı’nda son bulmaktadır. Bu noktadan itibaren Akdeniz’e açılabilmek için ise İstanbul ve Çanakkale Boğazları kullanılmaktadır (Uğurlu, 2009, s. 365). Görüldüğü üzere Türk Boğazları Rusya Federasyonu ve Karadeniz’e kıyısı olan diğer ülkelerin ekonomileri için son derece önemli bir geçit hüviyeti taşımaktadır.

\section{Istanbul Boğazı'nda Gemi Kaynaklı Çevre Kirliliği}

İstanbul Boğazı’nda oluşan gemi kaynaklı çevre kirliliğini ‘deniz kirliliği', 'hava kirliliği’ ve "negatif çevresel etkinin diğer boyutları' şeklinde üçlü bir ayrım ile inceleyebiliriz.

\section{Gemi Kaynaklı Deniz Kirliliği}

İstanbul Boğazı’nda iki tabakalı bir akım yapısı vardır. Yoğunluğu yüksek olan Marmara Denizi suları alt akıntı ile Karadenize taşınırken, yoğunluğu düşük olan Karadeniz suları üst akıntı ile Marmara Denizi’ne taşınmaktadır. Mevcut olan bu yoğunluk farkının nedeni Karadeniz ve Marmara Denizi arasındaki tuzluluk oranıdır. Karadeniz 18 psu (düşük) ve Marmara Denizi ise 38 psu (yüksek) tuzluluğa sahiptir. İşte bu yoğunluk farkı boğazdaki çift taraflı akıntıyı oluşturmaktadır. Ayrıca Karadeniz'in su seviyesi Marmara Denizi’ne göre daha yüksektir. "Bu su seviyesi farkı ise boğazdaki üst tabaka akımın kontrol etmektedir. Su seviyesi farkı meteorolojik etkilere ve Karadeniz’in hidrolojik değişimlerine bağh olarak zaman içerisinde değişiklik göstermektedir. Böylesi değişiklikler Boğaz'daki alt ve üst tabaka akımının kalınlı̆̆ını, ara kesit düzleminin yerini ve

7 “Liman Rusyày Akdeniz, Orta Doğu, Afrika, Güney ve Güney Doğu Asya ve Kuzey ve Güney Amerika’ya bağlayan uluslararası ulaşım koridorlarının birleştiği noktada bulunuyor. Rusyànın Güney ve Orta Bölgelerìnden - Ural, Volga Bölgeleri ve Orta Asya dâhil - nakledilen kargolar buradan dünyanın çeşitli limanlarına taşınıyor" (Denizhaber, 2016). 
akıntının şiddetini etkilemekte zaman zaman iki tabakal yapının ortadan kalkmasına dahi neden olabilmektedir." Nüfus artışı ve endüstrileşme İstanbul Boğazı̉nın su kalitesini de tehdit etmektedir. Kentin atık suları on arıtma tesisinde işlendikten sonra derin deniz deşarjları yoluyla Boğaz’nn alt akıntısına verilmektedir ${ }^{8}$. Bununla birlikte Karadeniz'den ve Marmara Denizi’nden gelen hissedilir bir kirlilik de söz konusudur. İstanbul Boğazı gibi farklı akım yapısına sahip sistemler "su kalitesi sıcaklık ve tuzluluk değişimleri, hidrodinamik değişimler (dalga, akıntı, gel-git, türbülans karışımı vb.), meteorolojik değişimler (rüzgar, hava sıcaklığı, atmosferik basınç değişimleri vb.) ve katı madde taşınım süreçlerinden de (birikim, tabandan su kolonuna ya da su kolonundan tabana geçiş, topaklaşma vb.) etkilenmektedirler" (Ayat ve Yüksel, 2012, s. 57-58).

İstanbul Boğazı uluslararası, ulusal ve yerel gemi trafiği, hızlı kentleşme, ticari balık avcılığı ve Karadeniz kaynaklı kirliliğin tehdidi altındadır. İstanbul Boğazı’ndan yılda yaklaşı 50.000 gemi geçiş yapmaktadır. Boğaz, küçük akarsularla evsel ve endüstriyel atıksu deşarjlarına maruz kalmaktadır. İstanbul Boğazı’nda kirlilik ölçümü için yapılan bir çalışmada yanma ve/veya petrol kökenli olabilen Poli-aromatik hidrokarbonların $(\mathrm{PAH})^{9}$ farklı noktalardaki (boğazın başından sonuna kadar karşılıklı 22 noktasında ve adalardaki 2 noktada) seviyesi tespit edilmiştir. "Evsel ısınma, endüstriyel işlemler, tam gerçekleşmeyen yanma prosesleri (süreçleri), motorlu araçların egzoz gazları gibi antropojenik (insan kaynaklı) kaynaklar ile orman yangınları gibi doğal kaynaklardan çevreye çok miktarda" poli-aromatik hidrokarbon girdisi olmaktadır. "Doğal su ekosistemlerinde yaygin olarak bulunan PAH'lar biyolojik süreçleri olumsuz olarak" etkilemektedirler. "İstanbul Boğazındaki PAH kirlenmesinin genel olarak Boğazın orta kısımlarında yüksek olduğu... Boğaz boyunca tüm örnekleme noktalarında yanma kökenli PAH’ların baskın olduğu” görülmüştür. En yüksek konsantrasyon İstinye noktasında bulunmuştur. İkinci en yüksek PAH konsantrasyonu ise yatların ve teknelerin bağlandığı bir nokta olan Tarabya'da tespit edilmiştir. "En düşük PAH konsantrasyonu, Boğazın Karadeniz girişinde bulunmuştur... Kirlenmenin kaynağına bakıldığında, genel olarak pirolitik kökenli olduğu gözlenmektedir. Evsel ısınma, çöplerin yakılması, yoğun araçve gemi trafiği PAH’ların İstanbul Boğazindaki en önemli kaynakları olarak özetlenebilir” (Karacık, Oktay ve Schramm, 2009, 6-9).

Günümüzde deniz taşımacılığının tamamında petrol ve türevi maddeler kullanılmaktadır. Petrol endüstrisinin ve pazarının büyümesi ile birlikte kaza sonucu çevreye petrol saçılması, depo tanklarından ya da boşaltım esnasında tankerlerden sızma ve atık petrol ürünlerinin yayılması gibi ciddi oranda çevre kirliliğine neden olan sorunlarla karşılaşılmaktadır. İstanbul Boğazı girişinde Haydarpaşa Garı açıklarında gerçekleşen Independenta Petrol Sızıntısı (1979) ${ }^{10}$ bu sorunların

8 “İstanbul Boğazının alt tabaka akıntısına verilen atıksu deşarjları, bu tabaka tarafından Karadeniz'in alt tabakasına taşınmaktadır. Bu taşınma esnasında iki tabaka arasındaki madde alışverişi nedeniyle alt tabakadaki kirletici maddenin bir kısmı üst tabakaya geçerek Marmara Denizine tekrar geri dönmektedir" (Tüfekçi, Kuzyaka, Bayram, Atabay, Mantıkçı, Beken, Tüfekçi, Akyol, 2016, s. 282-283).

9 PAH'lar organik bileşiklerin eksik yanması neticesinde oluşan toksik ve kanserojen etkiye sahip organik yapıdaki bileșiklerdir. "Doğal şekilde, orman yangınları veya volkanik patlamalarla olușur. İnsan kaynaklı oluşumları ise endüstriyel kaynaklar, motorlu taşıtlar ve sigara ile olmaktadır" (Alver, Demirci ve Özcimder, 2012, s. 45-46).

10 İstanbul'da meydana gelen diğer kazalar şunlardır: 1960, Peter Zoranic - World Harmony (Çarpışma), can kaybı 20, denize dökülen petrol 22.000 ton, yangın süresi 58 gün; 1964, Norborn (Batık Peter Zoranic ile Kanlıca önlerinde 
somutlaştığı bir hadise olmuştur. “... 15 Kasım 1979 tarihinde Haydarpaşa önlerinde Romen bandıralı Independenta tankerinin Evriali isimli bir Yunan tankeri ile çarpışması sonucunda 95.000 ton petrol denize dökülmüş, kazada 43 denizci hayatını kaybetmiştir" (Ceyhan ve Esmeray, 2012, s. 96). Bu kaza ve diğerleri göstermiştir ki trafik yoğunluğu, tehlikeli madde taşımacılı̆̆ı, artan gemi boyları, farklı akıntı yapısı ve iklim şartları, hassas çevre koşulları, diğer yerel tehlikeler, gemi trafiğine etki eden diğer denizcilik faaliyetleri, gemilerin ilerleyişini zorlaştıran dar su geçitleri gibi etkenlerden dolayı İstanbul Boğazı dünyanın diğer boğazlarına, kıyı ve iç sularına göre kaza riski son derece yüksek bir suyoludur. "Bir geminin geçmek için 12 kez rota değiştirmesi gereken boğazda son 50 yılda 500 kaza meydana gelmiş olup, boğazda halen 19 gemi enkazı bulunmaktadır” (Çevre ve Şehircilik Bakanlığı Çevre Yönetimi Genel Müdürlüğü [CSB ÇYGM], 2011).

Yoğun gemi trafiği, çevre üzerindeki olumsuz etkiyi her geçen gün daha da arttırmaktadır. Bu nedenle son dönemde bazı önlemler hayata geçirilmeye çalışılmıştır. Bu çerçevede İstanbul Boğazı̀nda gemi atıklarının "Denizlerin Gemiler Tarafından Kirletilmesinin Önlenmesi Hakkında Uluslararası SözleşmeMARPOL 73/78, Avrupa Parlamento'sunun ve Konseyinin 27.11.2000 tarihinde düzenlediği Gemilerden Kaynaklanan Atıklar İçin Liman Kabul Tesisleri içerikli 2000/59/EC Direktifi, 5216 sayıl Büyükşehir Belediye Kanununun 7. maddesi ve 26.12.2004 tarihli Resmi Gazetede yayımlanan Gemilerden Atık Alınması ve Atıkların Kontrolü Yönetmelĭ̆i’"gereğince gecikmeye neden olmayacak şekilde alınabilmesi öngörülmektedir (Yılmaz, Yetkin ve Yıldız, 2009, 407).

5216 sayılı Büyükşehir Belediye Kanununun detayına bakıldığında görev, yetki ve sorumluluklarla ilgili bölümünün 7. maddesi (i) bendinde büyükşsehir belediyelerine deniz araçlarının atıklarını toplamak, arıtmak ve bununla ilgili gerekli düzenlemeleri yapmak görevi verildiği görülmektedir. 5216 sayılı kanuna ve 25682 sayılı Resmi Gazetede yayınlanan Gemilerden Atık Alınması ve Atıkların Kontrolü Yönetmeliği’ne dayanarak "İstanbul İl sınırları içerisinde tüm limanlarda, demir yerlerinde ve iskelelerdeki deniz araçlarında oluşan Marpol EK-1: Petrol ve petrol türevi bulaşmış atıkların (sintine suyu ${ }^{11}$, slop, slaç, kirli balast, atık yă̆ v.b.) arıtılması amacı ile" Haydarpaşa Liman Sahası dahilinde Haydarpaşa Atık Alım Tesisi faaliyete sokulmuştur. Bu tesis ile gemi atıklarının kontrolü sağlanarak deniz kirliliğinin önlenmesi hedeflenmiştir. Ayrıca tesiste gerçekleştirilen arıtma sonucunda elde edilen petrol ve petrol türevli ürünlerin Çevre ve Orman Bakanlığından lisans alan 'bertaraf tesisleri’nde ikincil yakıt olarak kullanılması ve bu yöntem ile

çarpışmıştır), petrol kirliliği oluşmuştur; 1966, Lutsk - Kransky Oktiabr (Kızkulesi önlerinde çarpışma); 1982, Unirea, denize dökülen petrol 66.400 ton, gemi infilak ederek batmıștır; 1988, Bluestar - Gaziantep (Tankerler çarpışmıştır), denize dökülen ve havaya karışan amonyak gazı 1.000 ton (Gemi infilak tehlikesi nedeniyle Marmara Denizi’ne çekilmiştir); 1991, Madonna Lily - Rabunion18 (Çarpışma), Rabunion18 üç personeli ile batmış gemideki 22.000 hayvan telef olmuş, koyun ölüleri günlerce boğazdan toplanmıştır; 1994, Nassia (bir kuru yük gemisi ile çarpışmıştır), can kaybı 30, denize dökülen petrol 13.000 ton, yangın süresi 1 hafta; 1997, TPAO (Pendik Tersanesi'nde yanmıştır), can kaybı 2, denize dökülen petrol 1.500 ton; 1999 Semele - Şipka (Yenikapı açıklarında çarpışmışlardır), denize dökülen petrol 10 ton; 1999, Volganeft 248 (Florya açıklarında ikiye ayrılmıştır), denize dökülen petrol 1.500 ton; 2002, Gotia, denize dökülen petrol 25 ton; 2003, Svyatov Panteleymon, denize dökülen petrol 230 ton; 2010, Orçun C, denize dökülen petrol 125 ton (CSB ÇYGM, 2011, Kubilay, 2014, s. 38-39).

11 MARPOL ile yalnızca petrolden kaynaklanan deniz kirliliği değil, diğer zararlı maddelerden kaynaklanan kirlilik de ele alınmıştır. MARPOL Sözleşmesi, gemilerden denize deşarj edilecek sintine miktarını önemli ölçüde kısıtlamıştır. "Hatta Akdeniz, Baltık Denizi, Karadeniz, Kızıldeniz vd. gibi belli duyarl deniz alanlarında bunu tamamen yasaklamıştır” (Ayan ve Baykal, 2010). 
ekonomik kazanç sağlanması da öngörülmüştür (Yılmaz, Yetkin ve Yıldız, 2009: 406). Bu girişim İstanbul Boğazı’nda kirliliğin önlenmesi için önemli bir adım olmuştur. Ancak Boğaz’dan geçiş yapan gemiler sadece deniz çevresini olumsuz etkilememekte, İstanbul Boğazı’ndaki deniz trafiği sonucu ortaya çıkan emisyonlar da hava kirliliğine neden olmaktadır.

\section{Gemi Kaynaklı Hava Kirliliği}

İstanbul'daki hava kirliliği üzerine yapılan bir araştırma kapsamında Markakis vd.nin ortaya koyduğu üzere karayolu taşımacılığı tüm diğer faktörler arasındaki en önemli kirletici konumundadır. Karayolu taşımacılığı tek başına karbonmonoksitin (CO) \%83'ünden ve azot oksitlerin $\left(\mathrm{NO}_{\mathrm{x}}\right)$ \%79'undan sorumludur (Markakis, İm, Ünal, Melas, Yenigün, İncecik, 2012, s. 118). İstanbul'da son dönemde kömür kullanımının azalıp doğalgaz kullanımının yaygınlaşmasının çevreye olumlu etkileri olmuştur. Bu gelişmeyle ile birlikte kükürtdioksit $\left(\mathrm{SO}_{2}\right)$ konsantrasyonları hayli düşük seviyelerde görülmektedir. Bu pozitif durumun korunabilmesi ve devamlılığı için kömür kullanımının düşük miktarlarda tutulması gerekmektedir. Bugün İstanbul'un en önemli kirlilik sorunu olarak, "partikül madde $\left(P M_{10}\right.$ ve $\left.P M_{2.5}\right)$ ve azotdioksit $\left(\mathrm{NO}_{2}\right)$ kirliliği oluşan partikül maddelerin başlıca kaynakları, trafik, sanayi, yapılaşma, gemi trafiği, evsel ısınma ve doğal kaynaklardır (Sahra tozları, yollardan kalkan tozlar, vb.)”. Azotdioksit salınımı ise özellikle araç egzozlarından kaynaklanmaktadır. Bu kirleticilerden partikül madde sonucu oluşan kirliliğinin önlenebilmesi için trafik yoğunluğu nedeniyle oluşan kirliliğin ve plansız yapılaşmanın önlenmesi, doğalgaz kullanımının yaygınlaştırılması ve yeşil alanların çoğaltılması gerekmektedir. Azotdioksit kirliliğinin azaltılabilmesi ise trafikteki araç sayısının azaltılmasına ve şehir içi ulaşımda toplu taşıma araçlarının tercih edilmesine bağlıdır. Yine bu çerçevede "İstanbul'daki kirlilik kaynaklarından biri olan gemi kirliliğinin önlenebilmesi amacıyla, gemilerin kullandikları yakıtların belirli standartlarda tutulması gerekmektedir” (İST CSB, 2016, s. 23).

İstanbul Boğazı özelinde yapılan bir araştırma kapsamında Beşiktaş, Sarıyer ve Üsküdar'da bulunan üç hava kalitesi izleme istasyonunda yapılan ölçümlerde elde edilen değerler incelenmiştir. Yapılan inceleme sonucunda Beşiktaş bölgesindeki yıllık ortalama $\mathrm{NO}_{\mathrm{x}}$ değerlerinin yaklaşı \% 9 ,7'sinin mevcut boğaz trafiğinden kaynaklandığı tespit edilmiştir (diğer istasyonlarda $\mathrm{NO}_{\mathrm{x}}$ ölçümü yapılmadığı için bir değerlendirme yapılamamıştır). $\mathrm{SO}_{2}$ için bulunan yıllık ortalama değerler analiz edildiğinde ise her üç istasyonda boğaz trafiğinin hava kalitesine önemli negatif etkisi olduğu ve bu etkinin \%20'nin biraz üzerinde olduğu tespit edilmiştir. Araştırmaya göre $\mathrm{PM}_{10}$ kirlilik kaynakları içerisinde en az etkili olanıdır. "Beşiktaş ve Üsküdar'daki PM ${ }_{10}$ konsantrasyonlarına deniz yolu trafiğinin katkısı \%1'in altında kalmış, bu değer sadece Sarıyer için \%2,2 olmuştur. Bu da $P M_{10}$ 'nin diğer kirleticiler yanında çok önemli bir deniz yolu kaynaklı kirletici olmadığını ve daha çok ölçüm istasyonlarına yakın diğer yerel kaynaklardan (evsel ısınma, karayolu trafiği, vb.) oluştuğunu göstermektedir." Netice olarak, kirleticilerin etkisine genel olarak bakıldığında Sarıer'in 3 istasyon içinde mevcut boğaz trafiğinden en çok etkilenen bölge olduğu tespit edilmiştir. $\mathrm{Bu}$ durumun sebebi Sarıyer'in diğer istasyonların olduğu bölgelere göre boğazın daha iç kesimlerinde 
yer alması ve kirleticilerin dağılımını belirli düzeyde engelleyecek bir topoğrafyaya sahip olması şeklinde izah edilebilir (Tuna ve Elbir, 2013, s. 6). Kılıç’ın da belirttiği gibi "oluşan emisyonların sadece miktarının değil, meydana geldikleri zaman ve yerin de hava kirliliği tahminlerinde gerekli" olduğu görülmektedir ${ }^{12}$ (2009, s. 128). İstanbul Boğazı'nda kirleticilerin dağılımını engelleme ve rüzgar akışının kesilmesi noktasında özellikle Maslak semti civarına yapılan gökdelenlerin de öne çıktığı ileri sürülmektedir. Şahin, bu durumu şu şekilde ifade etmektedir “(Maslak’taki gökdelenler) Karadeniz'den gelen akışı, rüzgarı engelliyor. Rüzgar engellenince yazın ciddi bir problem olan 'isı adası' etkisi dediğimiz etki oluşuyor. Kış aylarında ise kirlilik oluşuyor. Şehre tamamen yüksek basınç alanı çöküyor ama bununla birlikte rüzgarları da kestiğinizde o rüzgarın kesilmesiyle birlikte şehir daha kirli bir yapıya bürünüyor" (Hürriyet, 2016). Bu araştırmalar ve tespitler gemi kaynaklı hava kirliliği seviyesinin geçiş güzergâhının yapısal özellikleri ile de ilişkili olduğunu göstermektedir.

Ne deniz kirliliği ne de hava kirliliğine ilişkin incelemeler gemilerden kaynaklanan negatif çevresel etkilerin tam anlaşılmasında yeterli olmaktadır. Denizyolu taşımacılığı ve gemilerin teknik özelliklerinden kaynaklanan bazı işlemler deniz çevresi ve ekosistemleri üzerinde çözülmesi oldukça güç problemlere neden olabilmektedir.

\section{Gemi Kaynaklı Negatif Çevresel Etkinin Diğer Boyutları}

Denizyolu taşımacılığının deniz ve hava kirliliğine neden olmasının da ötesinde uluslararası platformlarda üzerine vurgu yapılan kendisine özgü bazı çevresel sorunlar doğurduğu artık bilinmektedir. Balast suyu ile taşınan zararlı deniz canlıları belki de bu sorunların başında gelmekte, deniz çevresi doğal olmayan bir şekilde taşınan bu türlerden olumsuz yönde etkilemektedir. İki yönlü akıntı ile Marmara ve Karadeniz sularını belirli sürelerle barındıran İstanbul Boğazı’nın bu denizlerde oluşan bozulma ve değişimden etkilendiği görülmektedir.

Ekosistemlerin balast suları nedeniyle zarar görmesi doğal zenginliğe ciddi bir tehdit oluşturmaktadır. "Ekosistemlerin karmaşık ilişki ağları nedeniyle bir noktadaki müdahale, tür kaybı veya yeni tür girişi ekosistemlerde köklü değişimlere ve öngörülemeyen tahribatlara yol açabilmektedir." Örneğin Mnemiopsis leidyi adlı istilacı deniz canlısı Karadeniz'de görülen hamsi av miktarındaki düşüşte etkili olan bir faktör olarak değerlendirilmektedir (Atalay ve Toslak, 2013, s. 40-41). Hamsi, Çaça gibi balıklar zooplankton (mikroskobik deniz canlıları) ile beslendiklerinden jelimsi organizmalarla (Mnemiopsis leidyi gibi) besinlerini paylaşmak zorunda kalmaktadır. "Zooplankton miktarının azalmasıla birlikte jelimsi organizmaların balık yumurta ve larvaları ile beslenmeleri küçük pelajik balıkların (hamsi gibi) miktarında azalmaya neden olmuştur" (Birinci-Özdemir, Bat, Üstün, Şahin, Satılmış, Kıdeyş, 2007, s. 438).

Balast suları hakkında yapılan bir çalışma patojen (zararlı) bakteri varlı̆̆ı bakımından Marmara Denizi’nin önemli bir tehlike altında olduğunu göstermiştir (Altuğ, Gürün, Çardak, Çiftçi, Kalkan,

12 Buna ek olarak Kılıç tarafından yeterli veri bulunduğunda kullanılması tavsiye edilen 'bottom-up' yönteminde "gemilerin çalışma türleri manevra, seyir ve liman olmak üzere üçe ayrılmaktadır. Her çalışma türünde gemilerin ana ve yardımcı makinelerinin çalışma şartları değişmekte, bu da emisyon faktörlerinin değişmesine neden olmaktadır” (2009, s. 128). 
2012, s. 36-41). Amerika, Avustralya ve İngiltere gibi ülkeler bir süredir tanker balast suları yoluyla yayılabilecek zararlı deniz canlılarını tespit edip kontrol altına almakiçin limanlara gelen bazı gemilere (özellikle petrol tankerleri ile büyük yük gemilerine) denetim yapmaktadırlar. Bu denetimlerde tehlikeli görülen ya da kirlenmiş bölgelerden gelen gemilere karantina uygulanmaktadır. IMO da bu hususta açık denizde balast suyu değişimi uygulamalarını önermektedir (Altuğ, Çardak, Türetken, Gürün, Kalkan, 2013, s.73). "Yabancı egzotik türlerin bir ortama girdikten sonra mücadelenin ederi bu türlerin girişini engelleyici faaliyetlere göre çok daha pahalıdır." Bu nedenle zararlı canlılara karşı önleyici mekanizmalara başvurulmaktadır (Cirik ve Akçalı, 2002, s. 520).

İstanbul Boğazı’ndaki gemi trafik yoğunluğunun farklı negatif çevresel etkileri de tespit edilmiştir. $\mathrm{Bu}$ çerçevede öncelikle bazı balıkların varlığına ve göçlerine değinilebilir. İstanbul Boğazı’nda "Phocoenidae familyasindan Phocoena phocoena (Mutur) ile Delphinidae familyasından Tursiops truncatus (Afalina) ve Delphinus delphis (Tirtak)" adlı balıkların (setase ordosuna ait üç tür) varlığı bilinmektedir. İstanbul Boğazı, Marmara Denizi ve Çanakkale Boğazı́ndan oluşan Türk Boğazlar Sistemi’nin, Ege Denizi ve Karadeniz arasında önemli göç yolu olduğu ve setase (balinalar ve yunuslar) türlerinin ilkbaharda başlayan balık göçüyle birlikte İstanbul Boğazı’nın orta bölgesinde pelajik balıklarla beslendikleri tespit edilmiştir. Ancak "son yıllarda, yoğun deniz trafiği, aşırı avcılık, deniz kirliliğinin cetacea (setase) popülasyonlarını ve göçlerini olumsuz etkilediği bildirilmiştir” (Dede, Akamatsu, Öztürk, Tonay, Kameyama, Öztürk, 2016, s. 160-161).

İstanbul Boğazı sadece balıkların değil kuşların da göç yolu üzerinde bulunmaktadır. Trakya ve İstanbul Boğazı göçmen kuşların kullandıkları yollardan biridir. İstanbul Boğazı göç zamanında 250.000'in üzerinde leyleğin geçişine sahne olmaktadır. "Ayrıca yırtıcı kuş türleri (kartal, doğan, şahin, atmaca vb.), su kuşları (kaz, ördek, kuğu vb.), ötücü kuşlar (bülbül, saka, vb.) ve orman kuşları (çulluk, bıldırcın vb) bu göç yolunu yoğun bir şekilde kullanmaktadır” (CSB ÇİDGM, 2013, s. 198). İstanbul Boğazı’nda kirliliğinin (ş̧ık kirliliği, deniz ve hava kirliliği, gürültü kirliliği) minimum düzeyde tutulması göç eden hayvanların olumsuz etkilenmemesi açısından da önem taşımaktadır.

Üzerinde durulan genel çevresel sorunların mevcut veriler çerçevesinde bir gemi tipine özgü olarak ortaya konulmasının denenmesi ayırıcı bir dikkatle çözüme odaklanılmasını da beraberinde getirebilecektir. İstanbul Boğazı́ndan çok farklı gemi tipleri geçiş yapmakta, ancak gemi tiplerine göre farklılaşan / alternatif çevresel uygulamalar eksik kalabilmektedir. Bu düşünceyle Ro-Ro Gemileri kaynaklı negatif çevresel etkilerin - ve zenginleşen bilimsel çalışmalarla tüm gemi tiplerinin sebep olduğu farklı boyut ve nitelikteki zararların - ortaya konulmaya çalışılması alınacak özel / özgün tedbirlere katkı sağlayabilecektir.

\section{Ro-Ro Taşımacılığı ve İstanbul Boğazı'na Çevresel Etkisi}

\section{Ro-Ro Taşımacılığının Gelişimi}

Ro-Ro taşımacılığı firmalara rekabet gücü ve hız kazandıran bir ulaşım modudur. 'Ro-Ro' ifadesi İngilizce Roll-on / Roll-off teriminin kısaltılmış şeklidir (Özdemir ve Deniz, 2013, s. 105). Ro-Ro taşımacılığı raylı sistem araçları, kendi tekerleği ile hareket edebilen araçlar ile makine ve nakil 
vasıtalarının taşınmasını içermektedir. Ro-Ro gemileri ayrıca konteyner, dökme yük ve yolcu taşımacılığında da kullanılmaktadır. Ro-Ro gemilerinin önemli bir özelliği de yükleme ve boşaltma sırasında dikey işlem yerine rampalar sayesinde yatay işlem yapılmasına imkan vermesidir. Ro-Ro taşımacılığı genellikle yakın yol deniz taşımacılığında (short sea) kullanılmakla birlikte uzak yol taşımacılığında da (deep sea) Ro-Ro gemilerinden yararlanılmaktadır. Araştırmalar dünya denizyolu taşımacılığında kullanılan Ro-Ro gemilerinin küçüldüğünü ancak sayılarının arttığını ortaya koymaktadır. Bu çerçevede yakın yol deniz taşımacılığında kullanılan küçük Ro-Ro gemilerinin sayısında belirli bir artış olduğundan bahsedilebilir (Çakaloz ve Esmer, 2016, s. 87). Ro-Ro taşımacılığının da parçası olduğu 'multimodal taşımacılık' (denizyolu ile birlikte özellikle karayolu - demiryolu entegrasyonunun yapıldığı, iki den fazla ulaştırma modunun kullanıldığ 1 ulaştırma sistemi) ile dış ticarette müşteri memnuniyeti ve hizmet kalitesi açısından oldukça önemli bir yere sahip olan kapıdan kapıya (door to door) ulaştırma artık çok geniş coğrafyada mümkün hale gelebilmektedir (Çakaloz ve Esmer, 2016, s. 84-86).

Türkiyede Ro-Ro taşımacılığı ise ilk olarak 1985 yılında Trabzon limanında başlamıştır. Ro-Ro taşımacılığının hızlı bir gelişme trendi yakalamasında karayolu ile Avrupa’ya yapılan taşımalar esnasında sinırlarda yaşanan sorunlar; Balkanlar'da o dönemde yaşanan olumsuz siyasi gelişmeler ${ }^{13}$ ve bu gelişmelere bağlı olarak karayolu güvenliğinin azalması; otobanlarda alınan ücretlerin sürekli artışı ve Balkan ülkelerinin karayollarındaki altyapı eksiklikleri gibi olumsuz faktörler rol almıştır (Yeşilbağ, 1999, s. 415).

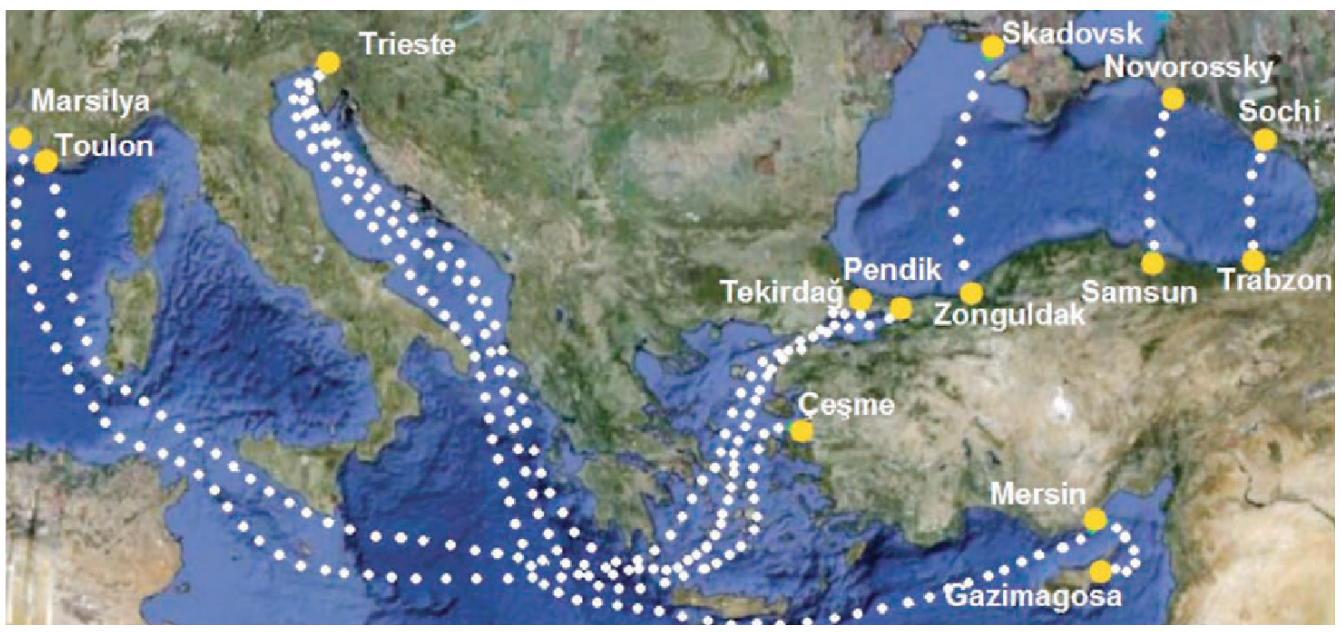

Harita 1: Türk Uluslararası Ro-Ro Hatları (UB, 2011, s. 96)

13 UND İcra Kurulu Başkanı Fatih Şener’in tespitine göre Türkiye’deki Ro-Ro taşımacılığı şartların zorlamasıyla başlamıştır: "Yugoslavya krizinde Türk araçlarının Avrupa'ya ulaşmasında sorunlar çıkınca taşımalar Ro-Ro ile yapılmaya başlanıyor. Görünürde çok pratik gelmiyor. Karayoluyla daha kısa sürede gidebileceğiniz bir yolu deniz yoluyla geçiyorsunuz. Bu bir çaresizliğin sonucuydu. Trieste ile başlayan bu yolculuk Fransa'ya kurulan hat ile devam etti... Türkiye'de çok sayıda Ro-Ro şirketi ve seferi var. İstanbul'dan neredeyse günde bir defa sefer yapıllyor. Avrupa'ya Türkiye'den her hafta 27 sefer Ro-Ro taşıması yapilyyor. Karadeniz'de 5 sefer, Akdeniz'de ise 14 sefer yapilyor" (Uluslararası Nakliyeciler Derneği [UND], 2017). 
Türkiye'de yurt dışı Ro-Ro hatlarının sayısı özellikle son yıllarda arttırılmış, 2010 yılından sonra açılan hat sayısı 16’ya ulaşmıştır. Bu çerçevede 2010 yılında Mersin-İskenderiye, SamsunKavkaz, Samsun-Tuapse ve Zonguldak-Yevpatoria hatları; 2011 yllında Ambarl1-Toulen, Samsun-Gelincik, Taşucu-Tripoli, İstanbul-Ilyichevsky, Zonguldak-Sevastapol, Tuzla-Köstence (Tuzla-Köstence daha sonradan talep yetersizliğinden dolayı kapanmıștır) hatları; 2012 yılında ise Taşucu-Tartous, İskenderun-Port Said ve İskenderun-Haifa hatları; 2013 yılında MersinDamietta, K.Ereğli-Ilyichevsky ve Derince-Poti hatları açılmıştır (Ulaştırma, Denizcilik ve Haberleşme Bakanlığ [UDH], 2014, s. 326).

\section{Istanbul Boğazı'nda Ro-Ro Gemileri Kaynaklı Çevre Kirliliği}

Ro-Ro taşımacılığının İstanbul Boğazı’na çevresel etkisi değerlendirilirken Boğaz’daki trafik yükünü oluşturan gemilerin özelliklerine göre gruplandırıldı̆̆ı veriler aydınlatıcı olacaktır. Aşağıda güncel rakamlarla geçiş yapan gemilerin özellikleri verilmiştir.

Tablo I: İstanbul Boğazı'ndan Geçiş Yapan Gemilerin Tiplerine ve Yıllara Göre Dağııımı (Deniz Ticareti Genel Müdürlüğü [DTGM], 20I7).

\begin{tabular}{|c|c|c|c|c|c|c|c|c|c|c|c|}
\hline YILLAR / Years & 2006 & 2007 & 2008 & 2009 & 2010 & 2011 & 2012 & 2013 & 2014 & 2015 & 2016 \\
\hline Barç & 63 & 47 & 52 & 53 & 28 & 17 & 2 & 19 & 12 & 17 & 6 \\
\hline Dökme Yük Gemisi & 5.419 & 5.145 & 5.978 & 6.635 & 5.863 & 6.341 & 7.163 & 6.898 & 7.263 & 7.485 & 7.664 \\
\hline Çimento Gemisi & 13 & 6 & & & 3 & 4 & 2 & 1 & 4 & 8 & 4 \\
\hline Konteyner Gemisi & 2.401 & 2.727 & 2.773 & 2.014 & 2.292 & 2.718 & 2.707 & 2.868 & 3.073 & 2.664 & 2.734 \\
\hline Feribot & 4 & 1 & 1 & & 1 & 3 & 1 & 1 & 4 & 2 & 1 \\
\hline Genel Kargo Gemisi & 33.082 & 34.822 & 32.735 & 30.840 & 30.876 & 29.288 & 27.126 & 25.521 & 24.107 & 22.412 & 21.344 \\
\hline $\begin{array}{l}\text { Canlı Hayvan Tașıyan } \\
\text { Gemi }\end{array}$ & 141 & 136 & 70 & 147 & 243 & 238 & 390 & 432 & 391 & 434 & 585 \\
\hline Savaş Gemisi & 168 & 166 & 200 & 180 & 114 & 94 & 129 & 196 & 237 & 318 & 342 \\
\hline Yolcu Gemisi & 1.658 & 1.702 & 1.147 & 786 & 631 & 481 & 583 & 474 & 649 & 444 & 291 \\
\hline Frigorifik Gemi & 908 & 819 & 805 & 623 & 602 & 441 & 248 & 204 & 65 & 24 & 40 \\
\hline Ro-Ro Gemi & 436 & 441 & 713 & 350 & 457 & 599 & 492 & 406 & 431 & 377 & 352 \\
\hline $\begin{array}{l}\text { Türü Belirtilmemis } \\
\text { Tanker }\end{array}$ & 7.659 & 7.204 & 6.564 & 6.557 & 6.464 & 6.216 & 5.912 & 5.685 & 5.587 & 5.825 & 6.033 \\
\hline $\begin{array}{l}\text { Kimyasal Yük Taşıyan } \\
\text { Tanker }\end{array}$ & 1.680 & 2.050 & 1.975 & 1.876 & 1.711 & 1.660 & 1.779 & 1.561 & 1.618 & 1.576 & 1.681 \\
\hline Gaz Tankeri (LPG/LNG) & 814 & 800 & 764 & 866 & 1.099 & 1.227 & 1.336 & 1.760 & 1.540 & 1.232 & 989 \\
\hline Römorkör & 294 & 253 & 313 & 304 & 293 & 245 & 274 & 241 & 231 & 282 & 237 \\
\hline Araç Taşıyan Gemi & 14 & 92 & 189 & 78 & 42 & 47 & 37 & 47 & 93 & 17 & 16 \\
\hline Diğer & 126 & 195 & 117 & 113 & 152 & 179 & 148 & 218 & 224 & 427 & 234 \\
\hline
\end{tabular}


Tablo 1'de Ro-Ro Gemilerinin İstanbul Boğazı'ndan 2016 yılında 352 geçiş yaptığı görülmektedir. 42.553 olan toplam gemi geçişi içerisinde bu rakam küçük bir yer tutmaktadır ${ }^{14}$. Son yıllarda Ro-Ro gemi geçişlerinin azalma eğilimi taşıdı̆̆ görülmektedir (2012-492, 2013-406, 2014431, 2015-377, 2016-352) ${ }^{15}$. Geçiş sayısının azalması, Ro-Ro gemilerinin özellikleri dikkate alındığında, ticari hareketlilikte bir düşüş eğilimi olduğunu da ortaya koymaktadır.

Ulaştırma Denizcilik ve Haberleşme Bakanlığı tarafından sunulan 'Yurt Dışı Bağlantılı Ro-Ro Hatları ve Taşınan Araç Sayısı' verilerinde görüldüğü üzere İstanbul Boğazı’ndan geçen TuzlaConstanta (Köstence) ve Derince-Poti hatlarında yoğun bir trafik yükü mevcut değildir. TuzlaKöstence hattında son dönemde sadece iki yıla ait hareket gözükmektedir. Bu hatta 2011 yılında 467, 2012 yılında 10.883 araç taşınmıştır (bu hat talep olmamasından dolayı aktif değildir). Derince-Poti hattında ise 2013 yilında 646, 2014 yilında 1.571, 2015 yılında 1.482 ve 2016'nın ilk 7 ayında 92 araç taşınmıştır (UDH, 2016, s. 377). Bakanlığa bağlı Deniz Ticareti Genel Müdürlüğü’nün 2014 yılında yayınladığı 'Ro-Ro Gemileri ile Taşınan Toplam Araç İstatistikleri’ne göre Derince-Poti hattında ise 2013 yllında 'Ro-Ro Gelen Gemi’ adedi 5, 2014 yllında ise 13'tür (DTGM, 2014, s. 75). Bu rakamlar yukarıdaki tablo ile birlikte değerlendirildiğinde İstanbul Boğazı'ndaki uğraksız (transit geçiş) Ro-Ro trafiğinin esas ağırlığı oluşturduğu ve negatif çevresel etki oluşturma bağlamında belirleyici olduğu ifade edilebilir.

\section{Ro-Ro Gemileri Kaynaklı Deniz Kirliliği}

Ro-Ro gemi hareketliliğinin yoğun olduğu yerlerde bu gemilerin üretmiş oldukları balast, sintine, evsel nitelikli atık sular ve çöp atıkları gibi kirleticiler görülebilmektedir. Gemilerin alt tarafında biriken ve yüksek oranda yağ içeren sintine suları paslanmaya neden olabileceği için belirli periyodlarda boşaltılmakta ve tabii bu durum denizlerde kirlenmeye sebebiyet vermektedir (Başar, 2010, s. 104-106). Ro-Ro gemilerinde bulunan yolcu sayısının da oluşabilecek kirlilik açısından önem taşıdı̆̆ı ifade edilebilir. Uluslararası kurallara göre bir Ro-Ro gemisi ek bölmelendirme ve emniyet tedbirlerine gerek görülmeden en fazla 12 yolcu taşıyabilmektedir. 12'den fazla sürücü ve yolcu alabilen Ro-Ro gemilerine ise Feribot denilmektedir (Yeşilbağ, 1999, s. 412). Gemi personelinin ve varsa yolcuların gemide kaldıkları süre içerisinde kullandıkları mutfak, lavabo, banyo ve tuvalet suları 'evsel nitelikli atık sular'ı oluşturmaktadır. Bunlardan 'siyah su (black water)' olarak da nitelendirilen tuvalet suları 'yüksek miktarda organik madde, azot, fosfor, koliform ve askıda katı madde barındıran" sulardır. Mutfak suları ise 'gri su (grey

14 Çanakkale Boğazı'ndan geçen Ro-Ro gemisi adedinin İstanbul Boğazına göre çok daha fazla olduğu dikkat çekmektedir (2016 yılında toplam 44.035 geçiş içerisinde 2.473). Çanakkale Boğazı́ndan gemi geçişlerinin son yıllarda artış eğilimi gösterdiği dikkat çekmektedir (2012-1.861, 2013-2.115, 2014-2.234, 2015-2.373, 2016-2.473) (DTGM, 2017) ki bu durum Türkiye-Avrupa Ro-Ro bağlantısının Marmara kıyılarındaki limanlardan (Haydarpaşa, Ambarl, Pendik, Tekirdağ) yapılmasından ileri gelmektedir.

15 Taşlıgil’in de ifade ettiği gibi Boğaz trafiğinin sadece gemi sayısına göre değerlendirilmesi hatalı olabilir. Bu noktada gemilerin büyüklükleri de dikkate alınmalıdır. Örneğin: "Boylarına göre gemiler 200 metreden büyük ve küçük olmak üzere iki kategoriye ayrilırsa 200 metreden küçük gemi sayısında 1997’den bu yana bir azalma olduğu görülmektedir. 1997'de 49083 olan sayı 2003'te 44016'ya düşmüştür. Bu durum dünya ticaret gemilerinin büyüme eğilimi göstermesinden kaynaklanmakta hatta gelecek yıllarda daha da azalması beklenmektedir" (2004, s. 8). 
water)' olarak nitelendirilmekte olup bunların koliform ve diğer kirletici madde içeriği daha düşük orandadır. Bu suların sığ bölgelere deşarjı ötrofikasyona neden olmakta; askıda katı madde ise suda bulanıklık oluşturmakta, dibe çökerek doğal yaşam ortamını olumsuz etkilemekte ve derinlik kaybına sebep olmaktadır (Başar, 2010: s. 106, Baykal ve Baykal, 1999, s. 124). Ro-Ro gemisinin türüne bağlı olarak personel ve yolcu sayısının fazlalığı nedeniyle ortaya çıkabilecek çöp atıkları da bu çerçevede dikkate alınmalıdır (Başar, 2010, s. 106).

Çevre ve Orman Bakanlı̆̆ı’nın 2011 tarihli yetki devri genelgesi ile İstanbul Büyükşehir Belediyesi gemi kaynaklı deniz kirliliğinin tespitine yönelik kıyılardan 5 mil açığa kadar olan alanda denetimler gerçekleştirmektedir (Ayrıca Liman Başkanlığı belirli bazı alanlarda, Sahil Güvenlik Komutanlığı ise bahsi geçen iki kurumun haricindeki alanlarda yetki sahibidir). İstanbul Büyükşehir Belediyesince yapılan bu denetimler ikişer denetçinin vardiyalı olarak görev yaptığı iki ekip tarafından "2 adet denetim teknesi, helikopter ve insansiz hava aracı (drone) ile sürekli olarak" gerçekleştirilmektedir. Ayrıca gemilerin tipine göre değil ancak ağırlıklarına göre 'atık' takip işlemleri gerçekleştirilmektedir (İstanbul Büyükşehir Belediyesi [İBB], 2016, s. 179, İstanbul Büyükşehir Belediyesi Deniz Hizmetleri Müdürlüğü [İBB.DHM], 2017). Bu denetimlerin etkinliği İstanbul Boğazı’ndaki deniz kirliliğinin kontrolü açısından son derece önemlidir.

Ro-Ro taşımacılığ 1 Karadeniz'de etkin bir şekilde yapılmaktadır. Başar, Erol ve Yılmaz’ın tespitine göre 2015 itibariyle Karadeniz'de yaklaşık 50 adet Ro-Ro gemisi bulunmaktadır. Bu gemilerden 6 adedi vagon taşıma kapasitesine sahip olup genellikle doğu-batı istikametinde çalışmaktadır. $\mathrm{Bu}$ gemiler Uluslararası Denizcilik Örgütü’nün sözleşme ve kuraları kapsamında bayrak devletlerinin yapmış olduğu denetimlerden geçirilmekte ve bunun yanında liman devletleri tarafından da kontrole tabi tutulmaktadırlar. "İlgili sözleşmeler gereği Karadeniz Memorandumu kapsamında denetim yapılan gemiler, sürekli aynı hatlarda çalıştığı için denetimlerin seviyelerinin düştüğü bilinmektedir." Çalışan Ro-Ro gemilerinin yaş ortalaması ise yüksektir (20 yaş üzeri) (2015, s. 80). Başar’ın da belirttiği gibi gemilerin "yüksek yaşlarda olması” çevresel açıdan olumsuz sonuçlar doğurabilecektir (2010, s. 109).

Karadeniz’deki Ro-Ro gemilerinin mevcut durumu - diğer gemilerle birlikte - gerek İstanbul Boğazı'na gerekse de Marmara Denizi’ne yapabileceği çevresel etkiler açısından önemlidir. Yukarıda da ifade edildiği gibi Marmara Denizinnin üst kısmında 25 metre derinliğe kadar Karadeniz sularına; alt kısmında ise Akdeniz/Ege sularına yakın özellikte iki tabakalı bir yapı bulunmaktadır. Ege Denizi ile Karadeniz arasındaki yaklaşı 55 cm'lik seviye farkı nedeniyle yılda yaklaşı 300 km³ Karadeniz yüzey suyu, İstanbul Boğazı yoluyla sürekli bir biçimde Marmara Denizine doğru akmaktadır. Ayrıca Marmara Denizi’nden Karadeniz istikametine bir alt akıntı da mevcuttur. "Böylece Marmara yüzey suları 4-5 ayda bir yenilenirken, alttaki sular 6-7 yılda bir yenilenmektedir. Üstteki sularm bu kadar hızl yenilenmesi, Karadeniz'deki çevresel sorunların anında Marmara’yı da etkileyebileceğini göstermektedir” (Kıdeyş, 2013, s. 81). Bu bilgilerden yola çıkılarak İstanbul Boğazı'ndaki deniz kirliliği sorununun çözümünün temelde Karadeniz ve Marmara'da yapılacak çalışmalarla ilgili olduğu ifade edilebilir. 


\section{Ro-Ro Gemileri Kaynaklı Hava Kirliliği}

Ro-Ro Gemileri ile yapılan taşımacılık, CEFIC (Avrupa Kimya Endüstrisi Konseyi) ve ECTA (Avrupa Kimyasal Taşımacılığı Birliği) tarafından 'Yük Taşımacılığı Faaliyetlerinden Kaynaklanan $\mathrm{CO}_{2}$ Emisyonlarının Ölçülmesi ve Yönetilmesi’ için hazırlanan kılavuzdaki 'CO $\mathrm{CO}_{2}$ Emisyonlarını Azaltma Olanakları' adlı kısımda 'daha yeşil' ulaşım modlarına geçiş için bir imkan olarak yer almıştır. Kılavuzda karayolu taşımacılığının yerine ikame edilecek olan kara-deniz-kara (roadshort sea-road) bağlantılı taşımacılığın emisyonların azaltılmasında bir firsat sunduğu ifade edilmiştir (The European Chemical Transport Association - The European Chemical Industry Council [ECTA - CEFIC], 2011, s. 14). Ayrıca Ro-Ro Gemilerinin $\mathrm{CO}_{2}$ emisyonlarının diğer gemi tiplerinin çoğuna göre daha az olduğu tespit edilmiştir. Uluslararası gemi nakliyesinden gemi tipine göre en yüksek $\mathrm{CO}_{2}$ emisyonunun Konteyner Gemilerinde (205) olduğu, onu Dökme Yük Gemilerinin (166), Petrol Tankerlerinin (124), Genel Kargo Gemilerinin (68), Kimyasal Madde Taşıyan Tankerlerin (55), Doğal Gaz Tankerlerinin (46) ve Kruvaziyer Gemilerinin (35) izlediği görülmektedir. Ro-Ro gemileri (29) ise bunlardan sonra gelmektedir (IMO, 2015, s. 41).

Kesgin ve Vardar'ın araştırmasına göre İstanbul Boğazı'ndan geçiş yapan gemiler içerisinde hava kirliliğinde en çok payı olanlar genel kargo gemileridir. Genel kargo gemileri toplam $\mathrm{NO}_{\mathrm{x}}$ emisyonlarının oluşumunda \%45'lik paya sahiptirler. Tankerler ise \%17'lik payla ikinci sıradadırlar. Ro-Ro gemilerinin İstanbul Boğazı'ndan geçen gemilerin oluşturduğu toplam $\mathrm{NO}_{\mathrm{x}}$ emisyonunda \%2'lik payı vardır ki bu oran diğer gemi tiplerine göre oldukça düşüktür. Aynı araştırmaya göre, İstanbul Boğazı'ndan geçiş yapan Ro-Ro gemileri için CO (karbonmonoksit), $\mathrm{CO}_{2}$ (karbondioksit), VOC (Uçucu Organik Bileşikler) ve PM (Partiküler Madde) toplamı da tüm gemiler içerisinde \%2 gibi düşük bir orandadır (Genel kargo gemileri \%45; Tankerler \%15) (2001, s. 1868).

Tuna ve Elbir'in yaptığı daha güncel bir çalışmada İstanbul Boğazı’ndan geçen gemi sayıları ele alınmış, 2011 yılında 29.267 geçiş ile kargo gemilerinin toplam gemi geçişinin \%59'luk kısmını oluşturduğu ifade edilmiştir. Ayrıca Boğazdan geçiş yapan tankerlerin ise \%13’lük oranla ikinci en yüksek geçiş sayısına sahip gemi türü olduğu belirtilmiştir. Çalışma şu tespitler yapılmıştır: "Farklı kirletici emisyonlarına katkı açısından bakıldığında, genel kargo gemilerinin yaklaşık \%50, tankerlerin ise \%15 gibi bir payı olduğu görülmektedir. (Bu çerçevede) kargo gemilerinin $N O_{\mathrm{x}}$ emisyonlarına olan katkısı \%46, tankerlerin ise \%17 olduğu belirlenmiştir” (2013, s. 5). Emisyon payları verilirken Ro-Ro Gemilerine değinilmemiştir, ancak bulunan sonuçların Kesgin ve Vardar'ın araştırmasındaki sonuçlarla uyum içerisinde olduğu anlaşılmaktadır.

\section{Ro-Ro Gemileri Kaynaklı Negatif Çevresel Etkinin Diğer Boyutları}

Bugün dünya denizlerindeki en büyük tehlikelerden biri "gemilerin balast suları (içerisinde) veya gemi karinalarına yapışma yoluyla yeni deniz alanlarına taşınan zararlı sucul organizmaların taşındıkları bölgelerde kalıcı popülasyonlar oluşturmaları"dır (Başar, 2010, s. 105). Denizdeki ekosistemleri bozan zararlı canlı türlerinin taşındığı balast suları esasen geminin boşken 
dengesini sağlama işlevi görmekte, yük alma ya da tersanelere yanaşma sürecinde denize deşarj edilmektedir. Ro-Ro Gemileri, LNG ve LPG (ham petrol ve sıvılaştırılmış gaz) taşıyan tankerler kadar olmasa da (bunlarda toplam DWT / Deadweight miktarının 1/4’ü kadar balast suyu kapasitesi mevcuttur), önemli oranda balast suyu kapasitesine (DWT’nin 1/5’i kadar) sahiptirler (Olgun, 2013, s. 156-158). Yukarıda balast suları ile Karadeniz ve Marmara Denizine taşınan zararlı deniz canlıları ile ilgili yapılan tespitler mevcut akıntının özellikleri nedeniyle İstanbul Boğazını da ilgilendirmektedir. Gemi Balast Suyu ve Sedimanlarının Kontrolü ve Yönetimi Hakkında Uluslararası Sözleşme’nin 8 Eylül 2017'de yürürlüğe girmesi bu noktada önemli bir adım olarak değerlendirilebilir.

İstanbul Boğazı’nda gemi kaynaklı oluşan diğer negatif çevresel etkiler çalışmanın ilgili kısmında incelenmişti. Burada şu husus belirtilmelidir ki Ro-Ro Gemilerinin - ve spesifik olarak diğer gemi tiplerinin - neden olduğu / olabileceği diğer negatif çevresel etkileri (Örneğin balık ve kuş göçlerine olan olumsuz tesirlerin derecesi) mevcut gemi trafiği içerisinde ayırmak yeni bilimsel araştırmaların ışı̆̆ında mümkün olabilecektir.

\section{Sonuç}

Uluslararası deniz taşımacılığı, kolaylaştırıcı özellikleri nedeniyle, dünya ticareti için büyük bir öneme sahiptir. Bu taşımacılık türü iktisadi hayata pozitif katkı ve canlılık sağlarken aynı olumlu tablo çevre ve ekolojik sistemler için söz konusu olmamıştır. Denizyolu taşımacılığı denizleri ve havayı kirletirken bunlarla beraber çevreyi ve doğal yaşamı da çeşitli yönlerden olumsuz etkilemiştir. Günümüzde bu etkiler ülkeler arasında - özellikle IMO’nun koordinasyonu ile uluslararası düzeyde işbirliği sağlanarak minimize edilmeye çalışılmaktadır. Gerçekten de artık küresel bir sorun halini alan gemi kaynaklı çevre kirliliği ve ekolojik sorunlar uluslararası, bölgesel ve ulusal düzeylerde koordinasyonu ve işbirliğini gerektirmektedir. Türkiye bu işbirliğinde üst düzeyde gösterdiği ilgi ve katılımlarla öne çıkmaktadır. Ancak bir deniz ülkesi olarak nitelendirilebilecek olan Türkiye'nin yüzleștiği bu sorunla daha etkin şekilde mücadele etmesi gerektiği de ifade edilebilir.

İstanbul Boğazı stratejik konumu ve uluslararası deniz taşımacılığındaki önemi itibariyle Türkiye açısından öne çıkan bir suyoludur. Karadeniz - Akdeniz bağlantısı ve ötesi bu boğazdan sağlanmaktadır. Çok işlek bir boğaz olması nedeniyle çevre sorunlarından ciddi oranda etkilenmektedir. Marmara Denizi ve Karadeniz'den mevcut akıntı yapısı nedeniyle direkt olarak etkilenen İstanbul Boğazı’nda deniz kirliliği giderek artmakta karasal boşaltımlara eklenen gemi kaynaklı deşarjlar deniz çevresi üzerinde olumsuz etkilere neden olmaktadır. Boğazdan geçen gemilerin hava kirliliğine neden olan emisyonları da bu çerçevede dikkatleri çekmektedir. Özellikle İstanbul Boğazı’nın belirli kesimlerinde dağılmayan kirli hava - karasal trafik de göz önünde bulundurulduğunda - insan sağllğına etki edebilecek seviyelere ulaşmıştır. Tüm bu sorunlarla birlikte gemi kaynaklı bazı faaliyet ve işlemlerin ekosistemlere de zarar verdiğine dair önemli bulgular vardır. Gemi balast suları ile taşınan ya da gemi karinalarına tutunarak 
doğal ortamlarının ötesine ulaşan istilacı deniz canlıları Marmara Denizi ve Karadeniz'deki ekosistemleri etkilemektedir. Bu etki İstanbul Boğazı’nda da hissedilmekte, deniz çevresi bu zararlı canlılardan olumsuz etkilenmektedir. Boğaz’daki gemi trafiğinin balık ve kuş göçlerini de etkileyerek ekosisteme negatif etkilerde bulunabileceği de bu çerçevede ifade edilebilir.

Araştırma kapsamında denizyolu taşımacılığı içerisinde pratik özellikleriyle ivme kazanan Ro-Ro taşımacılığının İstanbul Boğazı'na ne ölçüde negatif çevresel etkide bulunduğu mevcut veriler ışı̆̆ında tespit edilmeye çalışılmıştır. Bu çerçevede öncelikle Ro-Ro gemilerinin denizde ve havada oluşan kirliliğe etkisi, daha sonra da ortaya çıkan diğer çevresel olumsuzluklardaki spesifik payı tespit edilmeye çalışılmıştır. Araştırma sürecinde farklı gemi tiplerinin farklı negatif çevresel tesirler meydana getirdiği görülmüştür. Ro-Ro Gemilerinin ise özelde hava kirliliği açısından diğer birçok gemi tipine göre daha az olumsuzluğa neden olduğu tespit edilmiştir. Ancak deniz kirliliği ve diğer negatif çevresel etkiler ele alındığında dolaylı da olsa bu gemilerden kaynaklanan birçok problemin yaşanabileceği görülmüş; soruna gemi tipine özel teknik araştırma ve çalışmaların ışığında gerçekleştirilecek denetimler ve düzenlemelerle yaklaşılması gerektiği neticesine varılmıştır.

Araştırma kapsamında denizlerin bölgesel hatta global boyutta doğal bir etkileşim halinde olduğu ve bahsedilen negatif etkilerin sınırları tanımadığı görülmüştür. Bu etkilerin önlenmesi, azaltılması ve ortadan kaldırılması hedefi doğrultusunda çok yönlü bir yönetsel ve insani yaklaşımın geliştirilmesi yararlı olabilecektir. Sorunun çözümü yolunda ulusal, bölgesel ve küresel düzeylerdeki konsensüsle mesafe alınabileceği değerlendirilmektedir.

Küresel boyuta varan çevre kirliliği sorununun artık uluslararası piyasalardaki kısa ve orta vadeli maliyet ve rekabet hesaplarına kurban edilemeyecek derecede hayati bir konu olduğu açıtır. Kirlilik sorunundan sorumlu olan artık sadece devletler değil tüm toplumlar ve bireylerdir. Eğitim, özen ve çaba ile tüm seviyelerde mücadele edilerek sorunun daha fazla büyümesini engellemek olasılık dahilindedir. 


\section{Kaynakça}

Air Pollution \& Climate Secretariat - AirClim vd. (Air Pollution \& Climate Secretariat [AirClim], Seas At Risk, Bellona Foundation, North Sea Foundation, Transport \& Environment, European Environmental Bureau) (2011). "Air Pollution from Ships”. www.cleanshipping.org Erişim Tarihi: 11.11.2017

Altuğ, G. vd. (2012). “The occurrence of pathogenic bacteria in some ships' ballast water incoming from various marine regions to the Sea of Marmara, Turkey". Marine Environmental Research, Volume $81,35-42$.

Altuğ, G. vd. (2013). "Marmara Denizinin Mevcut Kirlilik Kaynakları ve Yansımalar”. Derdimiz, Değerimiz, Denizimiz: Marmara. (Ahmet Cihat Kahraman Ed.) İstanbul: Marmara Belediyeler Birliği Yayını.

Alver, E., Demirci, A. ve Özcimder, M. (2012). "Polisiklik Aromatik Hidrokarbonlar ve Sağllğa Etkileri”. Mehmet Akif Ersoy Üniversitesi Fen Bilimleri Enstitüsü Dergisi, Cilt 3, Say1 1, 45-52.

Atalay, M. A. ve Toslak, C. (2013). "Balıklandırma, Yabancı ve İstilacı Balık Türleri İle İlgili Ulusal ve Uluslararası Mevzuat”, İstanbul Üniversitesi Su Ürünleri Fakültesi, Yıl: 28, Sayı: 1, 39-62.

Ayan, M. ve Baykal, T.. (2010). "Uluslararası Denizcilik Organizasyonuna (IMO) Bağlı, Deniz Çevresinin Korunması Alt Komitesi (MECP) ve Bu Komitenin Bir Çalışma Sahası Olan Özel Alanlar (SA) ve Özel Duyarlı Deniz Alanları (PSSA)” Mevzuat Dergisi, Yıl 13, Sayı 146, (Şubat 2010) http:// mevzuatdergisi.com/2010/02a/02.htm Erişim Tarihi: 04.08.2017

Ayat, B. ve Yüksel, Y. (2012). "İstanbul Boğazı Su Kalitesinin Sayısal Modellemesi”. Türkiye Mühendislik Haberleri Dergisi, Y1l: 57, Say1: 471, 57-64.

Başar, E. (2010). “Trabzon Limanındaki Ro-Ro Gemi Trafiğinin Çevresel Açıdan Etkisi”. The First Global Conference on Innovation in Marine Technology and the Future of Maritime Transportation: Conference Proceedings Book. Nil Güler, Levent Kirval ve Ayşe Yllmaz (Ed.). İstanbul: Sena Ofset Ambalaj ve Matbaacilık.

Başar, E., Erol, S. ve Yılmaz, H. (2015). "Karadeniz Limanlarında Ro-Ro Taşımacılığı ve Gelişimi”. Ordu Üniversitesi Sosyal Bilimler Araștırmaları Dergisi (OÜSBAD), Sayı 12 (Temmuz), 71-82.

Baykal, B. B. ve Baykal, M. A. (1999). "Gemi Kaynaklı Evsel Atıksular ve Gemilerde Atıksu Yönetimi”. Gemi İnşaatı ve Deniz Teknolojisi Teknik Kongresi 99 - Bildiri Kitabı. A. İ. Aldoğan, Y. Ünsan ve E. Bayraktarkatal (Ed.). İstanbul: Yapım Matbaacılık.

Birinci-Özdemir, Z. vd. (2007). “Orta Karadeniz’de Ktenofor Mnemiopsis leidyi Türünün Boy Dağılımı ve Yumurta Verimi”, Türk Sucul Yaşam Dergisi, Yıl: 3-5, Sayı: 5-8, 437-444.

Ceyhan, N. ve Esmeray, E. (2012). "Petrol Kirliliği ve Biyoremediasyon". Türk Bilimsel Derlemeler Dergisi, Y1l: 5, Sayı 1, 95-101.

Cirik, Ş. ve Akçalı, B. (2002). "Denizel Ortama Yabancı Türlerin Taşınıp Yerleşmesi: Biyolojik İşgalin Kontrolü, Hukuksal, Ekolojik ve Ekonomik Yönleri”, Ege Üniversitesi Su Ürünleri Dergisi, Cilt: 19, Say1: 3-4, 507-527.

Çakaloz, B. ve Esmer, S. (2016). “Ulaştırma Sistemleri İçinde Ro-Ro Taşımacıllğının Önemi”. 5.Ulusal Lojistik ve Tedarik Zinciri Kongresi Bildiriler Kitabı. Mersin: Toros Üniversitesi İktisadi İdari ve Sosyal Bilimler Fakültesi Yayını.

Çevre ve Şehircilik Bakanlığı Çevre Yönetimi Genel Müdürlüğü - CSB ÇYGM. (2011). "Türkiye ve Dünyadaki Önemli Deniz Kazaları". http://www.cygm.gov.tr/CYGM/Libraries/GuncekBelgeler/ T\%C3\%BCrkiye_ve_D\%C3\%BCnyadaki_\%C3\%96nemli_Petrol_Kazalar\%C4\%B1.sflb.ashx Erişim Tarihi: 07.02.2017 
Çevre ve Şehircilik Bakanlığı, Çevresel Etki Değerlendirmesi, İzin ve Denetim Genel Müdürlüğü - CSB ÇİDGM. (2013). Çevre Durum Raporu 2012 Yllı Özeti - İller. Ankara: Altan Matbaacılık.

Çevre ve Şehircilik Bakanlığı, Çevresel Etki Değerlendirmesi, İzin ve Denetim Genel Müdürlüğü - CSB ÇİDGM. (2016). Türkiye Çevre Durum Raporu. Ankara: Sar Matbaa Yayıncılık.

Çevre ve Şehircilik Bakanlığı, Çevresel Etki Değerlendirmesi, İzin ve Denetim Genel Müdürlügü - CSB ÇİDGM. (2017). Denizlerde Bütünleșik Kirlilik İzleme Programı 2014-2016 Yllı Marmara Denizi Özet Raporu. Kocaeli: TÜBİTAK MAM Matbaası.

Dede, A. vd. (2016). "İstanbul Boğazı’nda Pasif Akustik İzleme Sistemiyle Setaselerin İzlenmesi (20092016)”. I. Ulusal Denizlerde İzleme ve Değerlendirme Sempozyumu, 21-23 Aralık 2016 Ankara (Bildiri Özetleri), 160-161.

Deniz Ticaret Odası - DTO. (2016). Deniz Sektörü Raporu 2015. İstanbul: İstanbul ve Marmara, Ege, Akdeniz, Karadeniz Bölgeleri Deniz Ticaret Odası.

Deniz Ticaret Odası - DTO. (2017). “İklim Değişikliği ve Emisyonlar”. http://www.denizticaretodasi.org.tr/ Sayfalar/iklimdegisikligi.aspx Erişim Tarihi: 25.08.2017

Deniz Ticareti Genel Müdürlüğü - DTGM. (2014). Deniz Ticareti 2014 Yll İstatistikleri: Deniz Taşıtları, Denizyolu Taşıma ve Teşvik İstatistikleri. Ankara: T.C. Ulaştırma, Denizcilik ve Haberleşme Bakanlığ 1 Deniz Ticareti Genel Müdürlügü.

Deniz Ticareti Genel Müdürlüğü - DTGM. (2017). “Türk Boğazları Gemi Geçiş İstatistikleri Ylllara Göre Karşlaştırma Tablosu” https://atlantis.udhb.gov.tr/istatistik/gemi_gecis.aspx Erişim Tarihi: 12.07.2017

Denizhaber. (2016). "Rusya’nın asırlık liman şehri: Novorossiysk". http://www.denizhaber.com.tr/rusyaninasirlik-liman-sehri-novorossiysk-haber-35531.htm Erişim Tarihi: 13.01.2016

European Environment Agency - EEA. (2015). Air Quality in Europe - 2015 Report. Luxembourg: Publications Office of the European Union.

Globallast.imo.org (2017). "Ballast Water as a Vector”. http://archive.iwlearn.net/globallast.imo.org/ globallast.imo.org/ballast-water-as-a-vector/index.html Erişim Tarihi: 14.08.2017

Hürriyet (2016). "Yüksek Binalar İstanbul'un Havasını Bozuyor" (Prof.Dr. Ahmet Duran Şahin’in Röportajı). http://www.hurriyet.com.tr/yuksek-binalar-istanbulun-havasini-bozuyor-40305203 Erişim Tarihi: 13.08.2017

İncecik, S. ve İm, U. (2013). “Mega Şehirlerde Hava Kalitesi ve İstanbul Örneği”. Hava Kirliliği Araștırmaları Dergisi, Cilt 2, Say1 4 (Ekim), 133-145.

İstanbul Büyükşehir Belediyesi - İBB. (2016). İstanbul Büyükşehir Belediyesi Faaliyet Raporu 2016. İstanbul: İstanbul Büyükşehir Belediyesi.

İstanbul Büyükşehir Belediyesi Deniz Hizmetleri Müdürlüğü - İBB.DHM. (2017). "Deniz Kirliliği Denetimi”. https://denizhizmetleri.ibb.istanbul/neler-yapiyoruz/deniz-kirliligi-denetimi/\#tab-id-5 Erişim Tarihi: 05.09.2017

İstanbul Çevre ve Şehircilik İl Müdürlüğü - İST CSB. (2016). İstanbul İli 2015 Yil Çevre Durum Raporu. İstanbul: İstanbul Çevre ve Şehircilik İl Müdürlügü.

Karacık, B., Okay O. S. ve Schramm K. (2009). "İstanbul Boğazı Boyunca Poli Aromatik Hidrokarbon Kirlenmesi ve Deniz Canlılarına Olan Etkisi”. Gemi ve Deniz Teknolojisi, Sayı: 179, 6-10.

Kesgin, U. ve Vardar, N. (2001). "A Study on Exhaust Gas Emissions from Ships in Turkish Straits". Atmospheric Environment, Volume 35, Issue 10 (April 2001), 1863-1870.

Kıdeyş, A. E. (2013). "Marmara Denizinin Mevcut Kirlilik Kaynakları ve Yansımalar”. Derdimiz, Değerimiz, Denizimiz: Marmara. (Ahmet Cihat Kahraman Ed.) İstanbul: Marmara Belediyeler Birliği Yayını. 
Kılıç, A. "Marmara Denizi’nde Gemilerden Kaynaklanan Egzoz Emisyonları”. Balıkesir Üniversitesi Fen Bilimleri Enstitüsü Dergisi, Cilt 11, Sayı 2 (Aralık 2009), 124-134.

Korkusuz, M. H. (2012). Mukaddime'den Muahhire'ye: Modern Dünyánın, Ulus-Devlet'in, Din'in ve Milliyetçiliklerin Ekonomi, Kültür ve Siyaset Atlası. 2.Baskı. İstanbul: Bilge Kültür Sanat.

Köseoğlu, B,, Töz, A. C. ve Şakar, C. (2016). “Deniz Atıklarının değerlendirilmesi ve Geri Dönüşümü: İstaç Örneği”. Dokuz Eylül Üniversitesi Denizcilik Fakültesi Dergisi, ULK 2015 Özel Sayı, 153-177.

Kubilay, H. (2014). “Türk Hukukuna Göre Boğazlar Rejimi: Çevre Hukuku Yönünden Değerlendirme”. İnönü Üniversitesi Hukuk Fakültesi Dergisi, Cilt: 5, Sayı: 1, 35-64.

Küçük, Y. K. ve Topçu, A. (2012). "Deniz Taşımacıllğıından Kaynaklanan Kirlilik”. Ankara Üniversitesi Çevrebilimleri Dergisi, Cilt: 4, Sayı: 2, 75-79.

Markakis, K. vd. (2012). "Compilation of a GIS Based High Spatially and Temporally Resolved Emission Inventory for the Greater Istanbul Area". Atmospheric Pollution Research, Volume 3, Issue 1 (January 2012), 112-125.

Marmara Denizi’nin Değişen Oşinografik Şartlarının izlenmesi Projesi - MAREM. (2014). Marmara Denizinnin Değişen Oşinografik Şartlarının İzlenmesi Projesi, 2013 Senesi Çalı̧̧ma Verileri (Ön Raporlar). (M. Levent Artüz Ed.) Ankara: Türkiye Barolar Birliği Yayınları.

Müstakil Sanayici ve İşadamları Derneği - Müsiad. (2013). Lojistik Sektör Raporu 2013. İstanbul: Müsiad.

Olgun, A. (2013). "Marmara Denizi Balast Suyu Riskleri”. Derdimiz, Değerimiz, Denizimiz: Marmara. (Ahmet Cihat Kahraman Ed.) İstanbul: Marmara Belediyeler Birliği Yayını.

Özdemir, Ü. (2012). “Türkiye’de Gemilerden Kaynaklı Deniz Kirliliğinin İncelenmesi”. Batman Üniversitesi Yaşam Bilimleri Dergisi, Cilt 1, Sayı 2, 373-384.

Özdemir, Ü. ve Deniz, T. (2013). “Zonguldak Limanı’nda Ro-Ro Taşımacıllğı”. Doğu Coğrafya Dergisi, Cilt 18, Say1 30 (Temmuz), 103-114.

Taşlıgil, N. (2004). “İstanbul Boğazı’nın Ulaşım Coğrafyası Açısından Önemi”. Marmara Coğrafya Dergisi, Sayı 10 (Temmuz), 1-18.

The European Chemical Transport Association - The European Chemical Industry Council - ECTACEFIC. (2011). "Guidelines for Measuring and Managing $\mathrm{CO}_{2}$ Emission from Freight Transport Operations”. https://www.ecta.com/resources/Documents/Best\%20Practices\%20Guidelines/ guideline_for_measuring_and_managing_co2.pdf Erişim Tarihi: 25.08.2017

The International Maritime Organization - IMO. (2011). "IMO and the Environment: IMO's Response to Current Environmental Challenges”. http://www.imo.org/en/OurWork/Environment/Documents/ IMO\%20and\%20the\%20Environment\%202011.pdf Erişim Tarihi: 25.08.2017

The International Maritime Organization - IMO. (2015). Third IMO GHG Study 2014: Executive Summary and Final Report. London: International Maritime Organization.

The International Maritime Organization - IMO. (2017a). “The International Maritime Organization”. http://www.imo.org/en/Publications/Documents/Attachments/distributors.pptx Erişim Tarihi: 14.08.2017

The International Maritime Organization - IMO. (2017b). "Structure of IMO". http://www.imo.org/en/ About/Pages/Structure.aspx Erişim Tarihi: 25.08.2017

The International Maritime Organization - IMO. (2017c). "International Convention for the Control and Management of Ships' Ballast Water and Sediments (BWM)" http://www.imo.org/en/About/ conventions/listofconventions/pages/international-convention-for-the-control-and-managementof-ships'-ballast-water-and-sediments-(bwm).aspx Erişim Tarihi: 25.08.2017 
Tozar, B. ve Güzel, E. (2011). “Enerji Lojistiği Perspektifinde Hazar Petrollerinin Türk Boğazlarına Etkileri”. Dokuz Eylül Üniversitesi Denizcilik Fakültesi Dergisi, Cilt 3, Sayı 2, 1-14.

Tuna, G. ve Elbir, T. (2013). "Kanal İstanbul Projesi Sonrası İstanbul Boğazı’nda Gemi Trafiğinden Kaynaklanan Hava Kalitesinde Beklenen Değişimlerin İncelenmesi”. Hava Kirliliği Araştırmaları Dergisi, Cilt 2, Sayı 1 (Ocak), 1-10.

Tüfekçi, V. vd. (2016). "Marmara Denizi İstanbul Çevresi Su Kalitesi Durum Değerlendirmesi”. I. Ulusal Denizlerde İzleme ve Değerlendirme Sempozyumu, 21-23 Aralı 2016 Ankara (Bildiri Özetleri), 282283.

Türkiye Cumhuriyeti Dışişleri Bakanlığı - MFA. (2017a). “Türk Boğazları”. http://www.mfa.gov.tr/turkbogazlari.tr.mfa Erişim Tarihi: 05.07.2017

Türkiye Cumhuriyeti Dışş̧leri Bakanlığı - MFA. (2017b). “Türkiye Cumhuriyeti Novorossisk Başkonsolosluğu”. http://novorossisk.bk.mfa.gov.tr/Mission.aspx Erişim Tarihi: 13.01.2017

Uğurlu, Ö. (2009). Çevresel Güvenlik ve Türkiye’de Enerji Politikaları. 1.Baskı. İstanbul: Örgün Yayınevi.

Ulaştırma Bakanlığı - UB. (2011). Türkiye Ulaşım ve İletişim Stratejisi: Hedef 2023. Ankara: T.C. Ulaştırma Bakanlığı.

Ulaştırma Denizcilik ve Haberleşme Bakanlığı - UDH. (2014). Ulaşan ve Erişen Türkiye 2014. Ankara: T.C. Ulaştırma Denizcilik ve Haberleşme Bakanlığı.

Ulaştırma Denizcilik ve Haberleşme Bakanlığı - UDH. (2016). Ulaşan ve Erişen Türkiye 2016. Ankara: T.C. Ulaştırma Denizcilik ve Haberleşme Bakanlığı.

Ulaştırma Denizcilik ve Haberleşme Bakanlığı, IMO Mevzuatı Bilgi Sistemi - IMO.UDHB. (2017). "IMO Sözleşmeleri”. http://imo.udhb.gov.tr/TR/sozlesme.aspx Erişim Tarihi: 05.09.2017

Uluslararası Nakliyeciler Derneği - UND. (2017). "Uluslararası Karadeniz Taşımacılık Forumu 2016 İstanbul'da Gerçekleştirildi” http://und.web.tr/tr/19214/uluslararasi-karadeniz-tasimacilik-forumu2016-istanbulda-gerceklestirildi Erişim Tarihi: 04.07.2017

Uluslararası Taşımacılık ve Lojistik Hizmet Üretenleri Derneği - Utikad. (2017). “Taşımacıların Gündeminde Tuna Nehri Var". http://www.utikad.org.tr/haberler/?id=11563 Erişim Tarihi: 04.07.2017

United Nations Conference on Trade and Development - UNCTAD. (2016). Review of Maritime Transport 2016. New York and Geneva: United Nations Publication.

Yeşilbağ, L. (1999). "Ro-Ro Taşımacıllğıının Ülkemiz Deniz Ulaştırma Sektöründeki Yeri”. Gemi İnşaatı ve Deniz Teknolojisi Teknik Kongresi 99 - Bildiri Kitabı, Ed.: A.İ.Aldoğan, Y.Ünsan ve E.Bayraktarkatal. İstanbul, 411-418.

Yılmaz, E., Yetkin, M. ve Yıldız, Ş. (2009). "Petrol ve Petrol Türevli Gemi Kaynaklı Atıksuların Bertaraf ve Yönetimi: İstanbul Örneği”. TÜRKAY 2009 Türkiye’de Katı Atık Yönetimi Sempozyumu Bildiriler Kitabl, Ed.: Ahmet Demir, Eyüp Debik ve Kâmil B. Varınca, YTÜ, 15-17 Haziran 2009, İstanbul, 405-412. 